\title{
The Economics of Gender Discrimination in Employee Fringe Benefits: Manhart Revisited
}

\author{
George J. Benston†
}

\begin{abstract}
The Equal Pay Act of 1963 generally prohibits employers from discriminating on the basis of sex by paying employees of opposite sexes unequal wages for equal work. ${ }^{1}$ Title VII of the Civil Rights Act of 1964 makes it unlawful for an employer "to discriminate against any individual with respect to his compensation, terms, conditions, or privileges of employment, because of such individual's race, color, religion, sex, or national origin."2 The Supreme
\end{abstract}

$\dagger$ Professor of Accounting, Economics, and Finance, Graduate School of Management, University of Rochester. In the interest of full disclosure, I should note that I was a policyholder elected trustee (1977-81) of the College Retirement Equities Fund ("CREF"), which along with its senior organization, the Teachers Insurance and Annuities Association ("TIAA"), is a principal codefendant in a number of lawsuits involving allegations of sex discrimination in annuity programs. See infra note 7. My wife and I also are members of a principal coplaintiff organization in these suits, the American Civil Liberties Union ("ACLU"), and we donate fairly heavily to the ACLU Foundation. In fact, we are likely to be beneficiaries of a prohibition against sex-distinct annuity tables for TIAA-CREF annuities, should the courts so rule, because we teach at perhaps the only university that does not require that contributions to retirement funds be deposited in TIAA or CREF regular annuity accounts. Since July 1976, we have put all our tax-deferred retirement contributions in CREF Supplemental Retirement Accounts ("SRAs"), which can later be withdrawn or "rolled-over" into other annuities rather than used to purchase TIAA-CREF annuities. (TIAA-CREF pension plan annuities permit only up to $10 \%$ of the accumulations to be withdrawn in cash at retirement.) If unisex annuity tables are mandated, my wife will purchase a unisex annuity with her funds, thus taking advantage of receiving greater periodic benefits than her actual life expectancy would allow, and I will withdraw my funds and place them with an insurance company or group that uses male life expectancy tables to calculate annuity payments. These latter annuity plans will be available to groups that do not discriminate but are in fact populated by males. See the discussion infra notes 151-58 and accompanying text for further explanation.

129 U.S.C. \& 206(d) (1976). The section provides in pertinent part:

No [subject] employer . . . shall discriminate . . . between employees on the basis of sex by paying wages to employees ... at a rate less than the rate at which he pays wages to employees of the opposite sex . . . for equal work on jobs the performance of which requires equal skill, effort, and responsibility, and which are performed under similar working conditions, except where such payment is made pursuant to (i) a seniority system; (ii) a merit system; (iii) a system which measures earnings by quantity or quality of production; or (iv) a differential based on any other factor other than sex.

1 Civil Rights Act of 1964, § 703(a)(1), 42 U.S.C. $\$ 2000 \mathrm{e}-2(\mathrm{a})(1)$ (1976). 
Court's application of these statutes ${ }^{3}$ in City of Los Angeles $v$. Manhart ${ }^{4}$ has invalidated the practice whereby employers administering their own pension plans required female employees to make larger pension contributions than similarly situated male employees in order to receive equal periodic payments upon retirement. ${ }^{5}$ By implication, Manhart also seems to invalidate the equivalent employer practice of providing lower periodic retirement payments to women whose pension fund contributions were equal to those of their male counterparts.

The practice invalidated in Manhart was based on the fact, acknowledged by the Court, ${ }^{6}$ that women, on average, live longer than men. This is the same fact that leads insurance companies to pay out less to female annuitants than to male annuitants of the same age for any given unit of a purchased annuity, and to charge men a higher premium than women for a given amount of life insurance issued at a given age. Several lower courts are now addressing the implications of Manhart for pension plans administered by private insurers rather than by employers; most notable are suits ${ }^{7}$ involving the fully-vested annuity programs administered by the Teachers Insurance and Annuity Association ("TIAA") and

3 Title VII's ban on sex discrimination with respect to "compensation," see supra text accompanying note 2, subsumes the Equal Pay Act's ban on sex discrimination with respect to "wages," see supra note 1. The Equal Pay Act's four statutory exceptions, see supra note 1, were specifically incorporated into Title VII by the "Bennett Amendment," Civil Rights Act of 1964, § 703(h), 42 U.S.C. § 2000 (e)-2(h) (1976). Thus the Equal Pay Act survives, ironically enough, as a source of possible defenses to actions alleging violations of Title VII. In City of Los Angeles v. Manhart, 435 U.S. 702 (1978), the appellant municipal department thus argued that its pension plan differentiated among employees with respect to longevity, a "factor other than sex" under the incorporated provisions of the Equal Pay Act. Id. at 711-13 \& nn.22-24.

435 U.S. 702 (1978).

s The "defined benefit" plan in Manhart provided for a monthly retirement amount computed as a fraction of an employee's salary multiplied by years of service, so that the periodic amounts paid to men and women of the same age, seniority, and salary during their lifetimes were equal. Id. at 705.

- Id. at 704 .

${ }^{7}$ See EEOC v. Colby College, 589 F.2d 1139 (1st Cir. 1978); Johnston v. Purdue Univ., No. L80-4 (N.D. Ind. filed Feb. 5, 1980); Peters v. Wayne State Univ., 476 F. Supp. 1343 (E.D. Mich. 1979); Spirt v. Teachers Ins. \& Annuity Ass'n, 475 F. Supp. 1298 (S.D.N.Y. 1979), motions for relief from judgment denied, No. 74 Civ. 1674 (S.D.N.Y. filed Mar. 19, 1982); Michigan State Univ. Faculty Ass'n v. Michigan State Univ., No. G76-640 (W.D. Mich. filed Dec. 15, 1976); American Nurses' Ass'n v. Teachers Ins. \& Annuity Ass'n, No. C75-558-G (M.D.N.C. filed Dec. 31, 1975); Bailey v. University of S. Cal., No. 75-3862 (C.D. Cal. filed Nov. 17, 1975).

s TIAA is a nonprofit legal reserve life insurance company established in 1918 by the Carnegie Foundation for the Advancement of Teaching. It provides retirement and insur- 
the College Retirement Equities Fund ("CREF"), which are offered primarily to employees of colleges, universities, foundations, and other educational and research organizations. Thus, the central issues in Manhart are still very much alive.

Insurers' use of sex-distinct mortality tables gave rise to a number of scholarly articles and notes before Manhart; $;^{10}$ this commentary made its way into the Manhart briefs, ${ }^{11}$ and certain of the arguments evidently influenced the Supreme Court's decision. ${ }^{12}$ Manhart in turn has provoked further debate, ${ }^{13}$ most notably

ance plans for educational institutions and their staff members.

- CREF was created in 1952 as a companion organization of TIAA to permit diversification into equity securities.

10 See, e.g., Bailey, Hutchison, \& Narber, The Regulatory Challenge to Life Insurance Classification, 25 Drake L. REv. INS. L. ANN. 779 (1976) (discussing the historical, conceptual, and practical bases for classifications and concluding that, in the context of insurance, discrimination is not necessarily illegal because antidiscrimination laws are concerned with unfair discrimination, not discrimination per se) [hereinafter cited as Bailey group]; Bernstein \& Williams, Title VII and the Problem of Sex Classifications in Pension Programs, 74 Colum. L. REv. 1203 (1974) (determining that Title VII requires employers to provide or purchase equal benefits for men and women); Gold, Equality of Opportunity in Retirement Funds, 9 LoY. L.A.L. Rev. 596 (1976) (concluding that Title VII requires contributions to, and benefits from, retirement funds to be equal and that the cost of female longevity should be spread among all employees); Lines, Sex-Based Fringe Benefits-Annuities and Life Insurance, 16 J. FAM. L. 489 (1978) (finding that Title VII currently bars disparate treatment in employee benefits, but concluding that the question is one of policy that Congress should resolve); Developments in the Law-Employment Discrimination and Title VII of the Civil Rights Act of 1964, 84 HARv. L. Rev. 1109, 1166-86 (1971) (concluding that Title VII requires evaluation on an individual basis rather than a prediction made based on a sex-defined group, but recommending adoption of a statutory exception that allows equal premium contributions by an employer, with unequal benefits, or that extends the sexdiscrimination ban to the insurance industry in general) [hereinafter cited as Developments]; Note, Sex Discrimination and Sex-Based Mortality Tables, 53 B.U.L. Rev. 624 (1973) (recommending that Congress bar the use of sex-segregated mortality tables by insurance companies) [hereinafter cited as B.U. Note]; Note, Equal Protection, Title VII, and Sex-Based Mortality Tables, 13 TULSA L.J. 338 (1977) (concluding that Title VII requires equal contributions and equal benefits); see also Comment, Gender Classifications in the Insurance Industry, 75 CoLuM. L. REv. 1381 (1975) [hereinafter cited as Columbia Comment]; Note, Sex Discrimination in Employee Fringe Benefits, 17 WM. \& MARY L. Rav. 109 (1975).

${ }^{11}$ See, e.g., Brief for Respondents at 19 (citing Developments, supra note 10); id. at 33 (citing B.U. Note, supra note 10); Brief for American Nurses Ass'n as Amicus Curiae in Support of Respondents at 15 (citing Gold, supra note 10).

${ }^{12}$ See 435 U.S. at 711 n.21 (citing Developments, supra note 10).

13 See, e.g., Bernstein \& Williams, Sex Discrimination in Pensions: Manhart's Holding v. Manhart's Dictum, 78 ColuM. L. REv. 1241 (1978) (concluding that Title VII bars consideration of a work force's sexual composition to determine any benefit plan's funding requirements because the use of unisex tables for only employer-operated plans would provide a disincentive to hire women); Freed \& Polsby, Privacy, Efficiency and the Equality of Men and Women: A Revisionist View of Sex Discrimination in Employment, 1981 AM. B. Found. Research J. 583 (arguing that Manhart was wrongly decided because use of sex- 
Spencer Kimball's fine critique of the opinion, ${ }^{14}$ and the strong counter argument by Lea Brilmayer, Richard W. Hekeler, Douglas Laycock, and Teresa A. Sullivan recently published by this journal. ${ }^{16}$

I argue in this article that the scholarly commentary that supports the Manhart opinion is seriously flawed, particularly in its conception of the value of the fringe benefit "insurance" to the individual. More importantly, I contend that Justice Stevens based his majority opinion in Manhart on the incorrect premise that periodic pension payments or insurance premiums that are based on sex-distinct mortality tables are unfair to individuals because "[m]any [individual] women do not live as long as the average man and many [individual] men outlive the average woman."16 In the course of my analysis, I consider the demographic arguments made by the Brilmayer group and find many of them to be erroneous. Finally, I argue that the maintenance and extension of the Manhart principles would be inconsistent with the congressional demand, expressed in the statutes, for equal treatment of individual employees with respect to sex. By focusing on the economic attributes of insurance-based fringe benefits, I hope to demonstrate that employee pension, annuity, and life insurance plans that do not use sex-distinct mortality tables in fact violate the Equal Pay

segregated mortality tables is justified by efficiency considerations); Key, Sex-Based Pension Plans in Perspective: City of Los Angeles, Department of Water and Power v. Manhart, 2 HARv. Women's L.J. 1 (1979) (concluding that Manhart has restricted significantly the use of sex as a risk-classification factor in employee group insurance but that other, more far-reaching questions remain to be decided by Congress, the state legislatures, and the courts); Rutherglen, Sexual Equality in Fringe-Benefit Plans, 65 VA. L. REv. 199 (1979) (concluding that the Manhart principle abolishing sexual classifications in fringe-benefit plans is workable and correct, even though the result is unequal treatment of the sexes).

14 Kimball, Reverse Sex Discrimination: Manhart, 1979 Am. B. Found. ReseArch J. 83 (concluding that the Manhart principle should be limited because it is based on the erroneous assumption that the Equal Pay Act and Title VII bar discrimination between the sexes, rather than discrimination against a person on the basis of sex) [hereinafter cited as Reverse Sex Discrimination]; see also Kimball, Reprise on Manhart, 1980 AM. B. Found. Research J. 915.

${ }^{15}$ Brilmayer, Hekeler, Laycock, \& Sullivan, Sex Discrimination in Employer-Sponsored Insurance Plans: A Legal and Demographic Analysis, 47 U. ChI. L. Rev. 505 (1980) (arguing that use of sex-based actuarial tables is illegal because the principle of Title VII is equal treatment of individuals, rather than equal treatment of groups, and challenging the widely accepted view that the relationship between sex and mortality is unchanging and uniform) [hereinafter cited as Brilmayer group]; see also Laycock \& Sullivan, Sex Discrimination as "Actuarial Equality": A Rejoinder to Kimball, 1981 AM. B. Found. RESEARCH J. 221.

16435 U.S. at 708. 
Act and Title VII.

\section{UNDERLYing AsSUMPTIONS}

My analysis rests on some basic assumptions that are best stated explicitly at the outset to avoid misunderstandings. First, I assume that the goal of both the Equal Pay Act and Title VII is to have individuals treated equally with regard to their race, color, religion, sex, and national origin in the sense that these personal attributes will not be treated invidiously. Thus the law does not prevent employers from distinguishing among individuals with respect to these attributes as long as the distinctions are demonstrably germane to the tasks for which a person is employed and do not mask otherwise illegal discrimination. ${ }^{17} \mathrm{I}$ base this assumption on a recognition that individuals naturally differ and that some of these individual differences may be related to race, color, religion, sex, and national origin. If these differences are not taken into account in a noninvidious way, affected individuals may be harmed or benefited as unfairly as if the differences were considered invidiously. ${ }^{18}$

Second, I assume that because the listed personal characteristics in the past have been, and possibly continue to be, the bases of unfair discrimination, their use in employment and other decisions is suspect. Therefore, those who use the criteria have the burden of demonstrating that such use is not based on bias and does not result in unfair discrimination against individuals. ${ }^{19}$ In this article, I accept the burden of showing that insurers' use of sex-distinct mortality tables for calculating the benefits from annuities and life insurance is necessary to avoid unfair treatment of people with respect to their gender.

Third, I assume that the Equal Pay Act and Title VII are not designed to reallocate resources in favor of persons of one sex, or otherwise to benefit or harm persons because of their gender. ${ }^{20}$ As I

${ }^{17}$ See Kimball, Reverse Sex Discrimination, supra note 14, at 103-05, for a more complete discussion. See generally Rutherglen, supra note 13, for a comprehensive description and analysis of the legal interpretations of racial and sexual discrimination.

1s See Wasserstrom, Racism, Sexism, and Preferential Treatment: An Approach to the Topics, 24 U.C.L.A. L. REv. 581 (1977), for a discussion with which I largely agree.

10 Freed \& Polsby, supra note 13, discuss the precedents and arguments that lead them to conclude that a per se prohibition of the use of an employee's gender is neither followed by the courts, contemplated in the statutes, nor desirable. Id. at 586-87. I concur with this conclusion. See infra notes 47-61 and accompanying text.

${ }^{20}$ Compare the analysis offered by Fiss, A Theory of Fair Employment Laws, $38 \mathrm{U}$. 
discuss below, ${ }^{21}$ however, forbidding the use of sex-distinct mortality tables in calculating the benefits of annuities and life insurance to an employee not only tends to reallocate resources on the basis of gender, but also tends to work against females who seek employment. Thus, the Manhart decision has policy results quite opposed to the goals that animated congressional action in this area.

\section{The Value of Annuities and Life Insurance to Individuals}

\section{A. Individuals versus Groups}

Almost all commentators and courts emphasize that Title VII refers to individuals, not groups. For example, two of the earlier commentators concluded: "In short, Title VII proscribes per se classification on account of sex, [or] that sexual classification which attributes to even a single individual a characteristic which he does not necessarily have, but [Title VII] permits differential treatment for pertinent characteristics the individual demonstrably possesses."22 Professor Brilmayer and her colleagues also emphasize this point, noting that Manhart relied on a disparate treatment theory in which "the essence of the [legislatively targeted] wrong is to ignore individual characteristics and treat individuals on the basis of group affiliation, as when an employer refuses to hire an applicant because he is black."23 Justice Stevens's opinion in Manhart stated that:

[Title VII's] focus on the individual is unambiguous. It pre-

CHI. L. Rev. 235 (1971). He concludes, in relation to the prohibition of racial discrimination in employment, "first, that the antidiscrimination prohibition is a strategy for conferring benefits on a racial class-blacks-and, second, that as a benefit-conferring strategy it is limited. It does no more than prohibit discrimination on the basis of race." Id. at 313. Considering the more limited societal demand for the elimination of distinctions based on gender discussed by Rutherglen, supra note 13, at 211, it seems clear to me that the statutes do not represent an attempt simply to benefit females over males.

${ }^{22}$ See infra notes 136-50 and accompanying text.

22 Bernstein \& Williams, supra note 10, at 1205 (footnote omitted).

2s Brilmayer group, supra note 15, at 509 (footnote omitted). The distinction between individuals and groups is discussed id. at 508-11 and is reemphasized throughout the paper. But the authors fail to distinguish between consideration only of individual characteristics that may be related to group characteristics, and the unjustified assumption of group characteristics. Thus they say that the "most fundamental principle [of the main civil rights tradition] has been that no individual shall be considered simply as part of a racial, sexual, religious, or ethnic group, or treated differently because of his membership in such a group." Id. at 508. The last phrase is not simply an amplification of the first part of the sentence. As $I$ argue below, refusing to treat annuitants differently because of their membership in sexual groups can be inconsistent with the fundamental principle of the civil rights tradition. See infra notes $42-46$ and accompanying text. 
cludes treatment of individuals as simply components of a racial, religious, sexual, or national class. If height is required for a job, a tall woman may not be refused employment merely because, on the average, women are too short. Even a true generalization about the class is an insufficient reason for disqualifying an individual to whom the generalization does not apply. ${ }^{24}$

The Manhart majority and most of the commentators, however, have incorrectly applied this correct statutory emphasis on the individual in the context of pensions and annuities, because they fail to understand what the individual employee gets when he or she is provided with insurance-based fringe benefits. ${ }^{25}$ Justice Stevens's analogy is particularly revealing: he evidently believed that he could adumbrate what is wrong with using sex-distinct mortality tables in employer-operated pension plans by referring to an example of sexual discrimination in hiring. Professor Brilmayer and her colleagues also make this mistake, citing the "classic illustration .... in which the employer refused to hire women for certain manufacturing jobs because employees in those jobs had to lift heavy weights."2s Determining the amount of compensation that employees should receive in the form of fringe benefits, however, is very different from deciding what criteria are appropriate in hiring decisions. The real question concerning fringe benefit compensation is whether it is unfair to pay men and women who are already employed different amounts because of their gender. To answer this question, one must determine the value to the employee of the fringe benefit in question.

Because they write for an insurance industry audience, insurance textbook authors and actuaries tend to explain insurance from the viewpoint of the insurer rather than from that of the insured. Thus they emphasize the mechanics of risk-sharing, which necessarily involves the law of large numbers and aggregations of

24435 U.S. at 708.

2s Notable exceptions are the Bailey group, supra note 10; Freed \& Polsby, supra note 13; Kimball, Reverse Sex Discrimination, supra note 14; and Rutherglen, supra note 13. The student authors of the B.U. Note, supra note 10, at 630, and Key, supra note 13, at 1315 , appear to recognize the essential issue, though they are not as clear as the others. None of these earlier authors, however, emphasized the essential economic issue as I would have preferred. Perhaps for this reason they were not persuasive to the Brilmayer group, supra note 15.

${ }^{26}$ Brilmayer group, supra note 15, at 510 (citing Bowe v. Colgate-Palmolive Co., 416 F.2d 711 (7th Cir. 1969)). 
individuals. ${ }^{2 \pi}$ To be sure, fairness to the insured is also stressed, in part because it is required by most state laws regulating insurance. These laws, however, usually describe fairness as the absence of "unfair discrimination between persons in the same class."28

From my reading of the legal literature and the Manhart briefs, I believe that commentators, lawyers, and the Court have been misled by these group-oriented descriptions of insurance. ${ }^{29}$ They appear to confuse the production of the product with its consumption, and the costs of production to the insurer with the value of the product to the insured. The following generalized description of insurance may help dispel the misunderstanding.

\section{B. Insurance Concepts and Individual Attributes}

Insurance in general provides a means for people to purchase compensation against the effects of the risk that some unwanted event might occur. In the case of life insurance, this event is the death of the insured; for annuities, the event is the impecunious survival of the annuitant. Both events are unwanted in the sense that, should they occur, the person or his or her beneficiary will

${ }^{27}$ See, e.g., 1 J. Greider \& W. Bgadles, Principles of Life Insurance 8 (rev. ed. 1972) ("insurance spreads among large numbers of people the economic losses actually experienced by some members of the group from such hazards as fire, automobile collisions, and early death"); see also B.U. Note, supra note 10, at 624 (citing, inter alia, S. HUEBNER \& K. BLACK, LIFE INSURANCE 34 (7th ed. 1969)) ("Insurance is a risk-spreading device based on probabilities of loss, utilizing statistics grounded on group expectations."). Key, supra note 13, at 11 \& nn. 77-79, gives almost the same description and cites the ninth edition of the same text. The Brilmayer group, supra note 15 , at 508 , also correctly states that "[t]he insurance tradition analyzes risks, premiums, and benefit schedules in terms of groups; most actuaries cannot think of individuals except as members of groups" (citing a TIAA-CREF statement: "Insurance by its nature requires reference to groups.").

${ }^{28}$ Bailey group, supra note 10 , at 806 . The authors summarize the state laws and regulations and discuss their histories and the implications of proposed changes that would prohibit or restrict classifications of risks. Id. at 806-07.

${ }^{29}$ For example, Professor Brilmayer and her colleagues describe the purpose of sexdistinct mortality tables in these terms:

Consider an annuity plan with two thousand participants, half male and half female, each of whom made equal contributions to the plan and retired at the same age. Proponents of segregated tables attempt to assure that the sum of all benefits paid to the thousand men will equal the sum paid to the thousand women-that sexual groups will be treated equally.

Brilmayer group, supra note 15, at 508 (footnote omitted). Aside from an additional analysis of the statutes and cases, leading to the conclusion that "unequal total payments to sexual groups are legal," id. at 522-23, and an extended discussion of the empirical relationship between gender and mortality, leading to a conclusion that these relationships are unreliable, id. at 539-59, this is the whole of the Brilmayer group's argument in support of Manhart and its extension to other employment-related pension plans. 
bear a cost. Should a person whose life is insured die, his or her beneficiary can be compensated in part with a cash amount; should an annuitant not die, the annuity provides resources (most often in the form of a pension) that he or she can use to pay living expenses.

To understand insurance, one must realize that the purchaser of a policy is not buying the amount that will be remitted should the unwanted event occur, but the promise that if the event occurs, the designated amount will be paid. Thus both the insured who does not die during the period covered by the life insurance policy and the insured who does have purchased and received the same product. Similarly, after a life annuity contract has been executed, an annuitant who lives for thirty years and an annuitant who dies the next day have both received the same product for their money. Furthermore, if it were possible to predict exactly when an event such as death would occur, there would be no insurers because there would be no risk to insure against. A person can save for an event that can be precisely predicted and need not pay someone else the administrative costs of assessing the probability of its occurrence. Moreover, it would be unlikely that an insurer could insure against the effects of such an event's occurrence at a price the insured would be willing to pay. Therefore, insurance necessarily involves circumstances in which the events insured against will not be precisely predictable, and in which the payments made to individual insureds will not be equal.

Assuming that the risk of the event occurring has been correctly and efficiently assessed, the amounts charged for the insurance should equal the present value of the expected payments ${ }^{30}$ plus the costs of administration. Otherwise, individuals are not treated equally; there is discrimination in the sense that they are charged premiums that are not functionally related only to the product that they are purchasing, namely, compensation for the effects of risk. It is necessary, therefore, to determine the expected amounts that will be paid to the insured should the event in ques-

so Present value refers to discounting the expected amounts of cash payments by a rate that measures the opportunity value of cash. If cash can be invested to yield $r$ percent (net of changes in the purchasing power of funds) in all time periods $(t)$, the present value of future cash flows $(c)$ received at the end of periods 1 through $t$ equals

$$
\frac{c_{1}}{1+r}+\frac{c_{2}}{(1+r)^{2}}+\ldots+\frac{c_{t}}{(1+r) t}=\frac{c\left[1-(1-r)^{-t}\right]}{r}
$$

Thus, if the investment or discount rate is positive, the present value of the expected cash flows is less than their value in the future. 
tion occur. This is what is meant by a "correct" assessment of risk. Administrative costs also will be incurred. These include the costs of making the necessary actuarial assessments (information costs) and the costs of keeping the required records, monitoring insureds so that false claims are not often paid, and informing insureds of the alternatives available to them. The insurer and insured benefit when the extra amounts spent on administration do not exceed the extra value to the insured of the expenditures. This is what is meant by an "efficient" assessment of risk.

From the insured's point of view, the means and factors used to produce insurance are relevant only if they affect its quality or price. In general, consumers need be concerned only with a comparison of the quality and price of alternatives; competition among producers usually results in the optimal use of production procedures and factors. But if constraints are placed on the insurers that prohibit them from using the optimal mix of productive factors, the insureds will be disadvantaged. In particular, if constraints forbid insurers from considering the characteristics of the individual insureds that affect the cost of insurance, the result will be invidious discrimination against some individuals and in favor of others.

Therefore, all information that will enable the insurer to assess the probability that the event will occur must be used if one insured is not to be unfairly advantaged or disadvantaged over another. To illustrate, consider a mutual insurance situation in which a group of people agree to contribute to funds that will pay a lifetime pension to the group members who achieve a given age, and a lump sum amount to the survivors of those who die. The task, then, is to calculate how much each of them should contribute, so that each pays a "fair" share-an amount that reflects only the cost of the risk each person imposes on the group. Assuming for now that there are no administrative costs, the group should use all information that predicts any difference in the probabilities of death of each member of the group. For example, if we know nothing about a member other than the fact that he or she smokes cigarettes, and if past experience indicates that, all other things being equal, smokers die sooner than nonsmokers, we would use this information to determine the probability that the members of the two subgroups will have different life expectancies. Experience has shown, however, that other things are likely to be associated with the life expectancies of the group members. For example, older people tend to die in fewer years than younger people, although 
some older people outlive some younger people. And the past experience of the particular group may indicate that females tend to outlive males, which generally has been found to be true, or that whites tend to outlive blacks, which has not been found to be generally true for annuitants. ${ }^{31}$

It is important to note that the assessment of the probability that an event will occur is a prediction of the future. Therefore, the experience of the past is of value only insofar as it provides an accurate prediction of the future. To achieve this, the relationship considered should be one that pertains to the specific group rather than to some other persons who are not members of that group. For example, the life expectancy of women may be adversely affected by the possibility of death in childbirth, but this event is irrelevant for predicting the life expectancy of female annuitants, because they are beyond the childbearing years when they attain the usual retirement age. Similarly, for calculating life insurance rates, the higher expected incidence of death among structuralsteel workers is irrelevant for estimates of the life expectancy of college professors.

The relationship between an attribute of an insured and the risk insured against should also be stable or predictable so that there is a good likelihood that it will hold in the future. This requirement has three dimensions.

One is that the magnitude of the attribute's effect must be measurable with sufficient accuracy to allow reasonably precise predictions to be made, given the costs of administration associated with more accurate predictions. For example, the age at which a person dies may be associated with his or her degree of nervousness. But the relationship may be very imprecise or have a very wide range, so that even though the life expectancy of a more nervous person, all other things being equal, is two years shorter than that of a less nervous person, there is still a ninety-five percent probability that the two types of person will live the same number of years. Thus, for any particular group over any reasonably finite time period, it is likely that nervous and calm persons will experience the same life expectancy, although over many groups and over a long period of time, the less nervous people will be found to have lived longer. If administrative costs were zero, however, the expected difference would properly be considered even in a small

s1 Evidence on these and other facts mentioned in this section is discussed below. See infra notes 67-123 and accompanying text. 
group because there would be no cost incurred in identifying the precise portion of the nervous who could be expected to die earlier.

The second dimension of stability and predictability is the expectation that the measured relationship will persist into the period when the benefits are paid. For example, though women may in the past have experienced shorter life expectancies because of childbirth deaths, that measured relationship between sex and life expectancy would be irrelevant for predicting the life expectancy of a female in the future if recent medical practice had sufficiently reduced the incidence of death in childbirth.

Third, and in many respects most important, the attribute must not be susceptible to selection by the insured for the purpose of defrauding the group. This is the problem of moral hazard. For example, there may be a reasonably predictable and stable relationship between the number of years and amount a person has smoked and his or her life expectancy. But if there is no practical way for the group to verify a person's claim to have been a nonsmoker or a light smoker, and if lower life insurance premiums are offered to people who did not smoke or who smoked little, it is likely that some past or present heavy smokers will deny their habits.

Another aspect of this problem occurs when an attribute associated with life expectancy is not considered. Then the group is subjected to adverse selection. For example, life expectancy may be positively associated with a person's own perception of his or her state of health and sense of general well-being. The person knows this perception, but the group cannot. Therefore the group will find that people who expect to live longer will purchase annuities, and those who expect to die sooner will purchase life insurance. For this reason, the group would be well-advised to base its predictions of life expectancy on its or others' actual experience with self-selected insureds.

As suggested by the above, administrative costs are an important factor because the assessment of probabilities and the monitoring of claims is not costless. All useful attributes of the individual members of the group should be used to predict the occurrence of events and the expected amounts that will be paid, provided that the costs of the assessment do not exceed the benefits derived from it. For example, assume that individuals' prior smoking habits affect the probability of their deaths, so that those who have smoked two packs a day for ten years increase the probability of their deaths at age sixty-five by ten percent, at age sixty-seven by 
twelve percent, and so on. (A complete schedule relating the amount and period of smoking at various ages to the probability of death at various ages would have to be constructed). As a consequence, one could calculate the present value of the expected amounts that would be paid as annuities to these persons at and after age sixty-five, as compared with the amounts paid to nonsmokers. Say that for a heavy smoker, these calculations call for a reduction of $\$ 1200$ in his annuity's cost because he could be expected to die sooner and collect less. But the cost of measuring those relationships also must be incurred. And, often of greater importance, it is costly to establish the smoking history of a particular person. Because these administrative costs would be incurred for the benefit of the annuitant who smokes, lowering his cost, they should be charged to him. If these administrative costs exceed $\$ 1200$, the smoker would prefer not to pay them and not to have the calculations made. Conversely, if life insurance were the product offered, and if the costs of assessing the higher probability of an insured smoker's earlier death exceeded the amount of higher premiums that would be charged the smokers, the nonsmokers would be better off if the assessment were not made.

Therefore, the individual members of an insured group benefit from the identification and application of relationships associated with the occurrence of the event insured against only when the expected savings exceed the costs. In many instances this is unlikely to occur, for several reasons. First, the assessments may be very costly to make. Second, they may not be stable; as a consequence, predictions of the amount of the expected savings may be too unreliable. Third, the costs of administering and monitoring the assessments so that the group is not defrauded by some of its members may be too great. For these reasons, insurers tend in practice to make relatively few distinctions among individuals, and the individuals ultimately benefit thereby.

\section{Cross-Subsidization}

A good illustration of the prevalent misunderstanding of insurance as a consumer product may be found in one of Justice Stevens's comments in Manhart. In speaking of group insurance, he said:

[W]hen insurance risks are grouped, the better risks always subsidize the poorer risks. . . . Treating different classes of risks as though they were the same for purposes of group in- 
surance is a common practice which has never been considered inherently unfair. To insure the flabby and the fit as though they were equivalent risks may be more common than treating men and women alike; but nothing more than habit makes one "subsidy" seem less fair than the other. ${ }^{32}$

Professor Kimball cogently discusses one important misconception revealed in this quotation: namely, that insuring people who represent different risks for the same price "has never been considered inherently unfair." As Kimball points out, this practice may indeed be unfair if other factors that are gained through group insurance, such as lower administrative and marketing costs, do not offset the unequal risks of the participants, so that all are better off, though some more so than others, with a group policy than with individual policies. ${ }^{33}$

But Kimball does not go far enough, because he does not point out that, from the viewpoint of the insured, there are really no subsidies. The insured receives something of value, the right to collect a given amount if an event occurs, for which he or she pays either directly or indirectly, by receiving a fringe benefit in exchange for work. The value of that contingent right to the insured depends on his or her estimate of the probability of the event occurring and the relative desirability of cash now versus in the future. Whether or not someone else can obtain that good at a higher or lower price-that is, whether or not the other's compensation is lower or higher-is of interest only in two principal regards. One is whether unequal compensation is paid for equal work in contravention of the statutes. The second involves a possible mutuality among the insureds, as where the amounts charged and paid are dependent on their joint experiences. This is the situation in mutual insurance associations and for group policies, in which the premiums are based on the experience of the insured group. But even in this situation, there are no subsidies as long as each insured has the freedom to obtain insurance elsewhere, but chooses to be a member of the group because the advantages are preferable to the alternatives. These advantages, and some disadvantages, are considered next in the context of the employment situation.

32435 U.S. at 710 (footnotes omitted).

${ }^{33}$ Kimball, Reverse Sex Discrimination, supra note 14, at 106-08. 


\section{Calculating the Value of Insurance to an Individual Employee}

To summarize, the value of any form of insurance to the insured is measured by the present value of the amounts promised multiplied by the probability that the event insured against will occur, where the probabilities are assessed as accurately as possible, considering the costs and benefits of making these assessments and controlling for the effects of moral hazard and adverse selection. To this expected present value should be added a money equivalent of the value to the insured of avoiding the effects of risk. Thus, the actual amounts received do not measure the benefit received by an employee who is granted insurance as a fringe benefit. ${ }^{\text {st }}$

One other important point should be mentioned before these concepts are applied to the question of gender discrimination in the use of sex-distinct mortality tables. The value of the insurance fringe benefit to employees depends not on its cost to the employer but on its subjective worth to the individual recipient. This is the situation for any compensation not paid in cash. As an initial approximation, the value of a fringe benefit to an employee seems to equal the number of dollars he or she would pay to purchase the same benefit on the open market. But personal income taxes play an important role because most fringe benefits, including annuities

34 A frequently stated misconception in the commentaries and Manhart briefs is that the amount of annuity payments actually received measures the value of the fringe benefit to the employee. (Rutherglen, supra note 13, at 248-49, and Kimball, Reverse Sex Discrimination, supra note 14, at 97-102, are important exceptions.) For example, Bernstein \& Williams, supra note 10 , equate the benefits of an annuity with the monthly amounts actually received, arguing that "[i]f Title VII requires equality in benefits, it requires equality in monthly benefits rather than actuarial equivalence for men and women over their average lifetime." Id. at 1211-12. Similarly, Justice Stevens in Manhart incorrectly equated "benefits" with the amounts eventually received. 435 U.S. at 710 n.20 ("each retiree's total pension benefits are ultimately determined by his actual life span") (emphasis in original). The Labor Department Wage and Hour Division's regulations for Title VII probably have contributed to this error. They provide: "In the area of employer contributions for insurance, pensions, welfare programs and other similar 'fringe benefits' the employer will not be considered to have violated these guidelines if his contributions are the same for men and women or if the resulting benefits are equal." 41 C.F.R. $\$ 60-20.3$ (c) (1981). This regulation makes sense only if "the resulting benefits" are measured as described above, as the present value of the expected periodic payments. (Even so, the regulations assume that the cost to the employer is at least as great as the value of the fringe benefit to the employee. The possibility that women or blacks value these benefits less when they are not immediately vested is overlooked). If the "benefits" are taken to be the periodic payments, however, as they were by the Wage and Hour Division Administrator and Justice Stevens, not only is the word "benefits" misused, but the two amounts can be equal only where the life expectancies and other attributes of the employees are identical. 
and most other insurance, do not represent taxable income to the recipients and, when purchased individually, do not result in deductions from taxable income, with the notable exception of taxdeductible contributions to Individual Retirement Accounts ("IRAs") ${ }^{35}$ and to Keogh Plan accounts. ${ }^{36}$ An annuity that would cost $\$ 1000$ on the open market is thus worth more as a fringe benefit to an employee in the fifty percent marginal tax bracket than to an employee in the twenty percent bracket. But for several reasons some employees may not initially value an annuity at the amount it would cost them to purchase it. They may believe they can invest their funds at a higher yield, net of administrative and other transaction costs, than the yield implicitly promised by the insurer. They may prefer to have the cash now rather than in the future, which is to say that they may apply a greater discount rate than that promised by the insurer. Or they may assess a lower probability than the insurer that they will live to collect the periodic amounts promised. In addition, if the pension offered by the employer does not vest immediately, the employees will assess the probability that they may not stay long enough to collect the promised fringe benefits. ${ }^{37}$

It should be emphasized that the cost of the annuity to the employer is irrelevant to the employee, particularly as concerns a possible violation of the Equal Pay Act and Title VII. But it is likely that in most situations, the cost of an annuity or other fringe benefit to the employer is less than its value to the employee, for two principal reasons. One is the tax advantage to the employee. ${ }^{38}$ The other is the lower price per contract charged by insurers to employers because of administrative and marketing economies

ss I.R.C. $\S 219$ (West Supp. Nov. 1981).

se Id. § 404(e).

37 Thus, the value of a fringe-benefit annuity to an employee can be determined as follows: $\mathrm{VA}=(\mathrm{MA} \cdot(1-d) \cdot p) /(1-t)$, where

$\mathrm{VA}=$ the value of the annuity to an employee;

MA = the market price at which the employee could purchase the annuity;

$d=$ the discount applied to the annuity when the employee values it at less than its market value ( $d$ can be negative if an employee believes that the insurer can obtain a higher return on funds because of economies of scale, diversification, and expertise); $p=$ the probability that the employee will stay long enough to get a vested right to the annuity, when it does not vest immediately; and

$t=$ the marginal personal income tax rate, because the annuity is nontaxed compensation. (This rate should be decreased sufficiently to account for the present value of future taxes on the annuity principal. It also should be applied to MA if the person can deduct from taxable income direct contributions to an annuity plan.)

s8 Denoted by $1 /(1-t)$. See supra note 37 . 
from bulk or group contracts as compared to individual ones. ${ }^{39}$ The major exceptions to this generalization involve young people, who are likely to have high discount rates, and, where pension rights do not vest immediately, ${ }^{40}$ short-term employees. This last factor should be considered with respect to possible Equal Pay Act and Title VII violations. If the most effective predictor of an employee's acquisition of a vested right to a pension is his or her gender or race, ${ }^{41}$ the total compensation paid is a function of these attributes, and the compensation paid to those who are predicted to leave before vesting would actually be lower than the apparently equal compensation paid to others.

\section{Application to the Use of Sex-Distinct Mortality TABLES}

\section{A. Violations of the Statutes}

I have argued that insurance providers must consider the personal attributes of insureds that are related to the expected amounts promised and the administrative and monitoring costs that are efficiently incurred. If they do not, some insureds will be unfairly discriminated against. In particular, if an insured's gender is an efficient predictor of his or her life expectancy, and if it is not used to determine the amount that will be paid as an insurance award or periodic pension payment, then the employer arguably will have violated the Equal Pay Act ${ }^{42}$ because the value of fringe

30 Van Alstyne, Equality for Individuals or Equality for Groups: Implications of the Supreme Court Decision in the Manhart Case, 64 AAUP BULL. 150, 155 (1978), argues that the major concern is benefit to the employee, not cost to the employer, but implies that the value of the amount to the employee is not likely to be greater than the cost to the employer; he does not consider the tax advantages of receiving fringe benefits and the economies of group purchasing. Van Alstyne is cited approvingly by the Brilmayer group, supra note 15 , at 517 n.54.

¿0 The Employee Retirement Income Security Act of 1974 ("ERISA"), § 203(c), 29 U.S.C. $\$ 1053$ (c) (1976), provides that amounts contributed by employees are $100 \%$ vested, but that amounts contributed by the employer need not begin vesting until the employee completes five years of service. The annuities provided by colleges, universities, and similar organizations through TIAA-CREF are immediately vested and are portable. The employees "own" their accounts: when they die, their heirs obtain the amounts credited thereto, including earnings.

'1 For example, if women and blacks tend to leave before their benefits fully vest, their compensation is lower than that paid to men and whites, all other things being equal.

"2 The fringe benefits of insurance and pensions are clearly compensation or "pay" to the employee. There is some question whether they are considered "wages" as that term is used in the Equal Pay Act. See supra note 1. Kimball, Reverse Sex Discrimination, supra note 14 , at $98-99$, and Bernstein \& Williams, supra note 10 , at 1211,1214 , agree that the 
benefits to its employees will be affected unfairly due to the employees' gender classifications. Thus, assuming for now that, all other things being equal, women are expected to live longer than men, ${ }^{43}$ granting the same periodic life pension to a male and a female employee of the same age who do the same work gives lower present compensation to the male than to the female. If the same amount of life insurance coverage were given to these employees, the male would receive a greater fringe benefit than the female. Because these differences in pay are determined solely by the gender of the employees, I conclude that this practice violates the Equal Pay Act and section 703(a)(1) of Title VII."4

Furthermore, if an employer were forced by, say, a union contract into giving as fringe benefits equal amounts of annuity pension payments or life insurance awards to similarly situated male and female employees, I conclude that the employer would violate section 703(a)(2) of Title VII, which prohibits employers from classifying their employees in a way that might deprive them of employment opportunities because of their sex.45 If an employer is forced to pay higher compensation to a woman employee in the form of pension benefits or to a male employee in the form of life insurance, these otherwise similarly situated employees will necessarily be less desirable to the employer. Because the magnitude of

benefits are wages, but disagree on how the value of the benefits should be measured.

${ }^{43}$ I consider the evidence behind this assumption infra part IV. It should be emphasized that longer life expectancy, as it is considered at this point, is a characteristic shared by every individual woman; actual longer life is a group trait because it appears when one averages the lives of individual women.

"See supra notes 1-2 and accompanying text. Recently both the Office of Federal Contract Compliance Programs ("OFCCP") and the Equal Employment Opportunity Commission ("EEOC") proposed revisions to regulations concerning equality of fringe benefits for male and female employees under Executive Order 11,246, 3 C.F.R. 339 (1965), and the Equal Pay Act, 29 U.S.C. $\$ 206$ (d) (1976), for which they are respectively responsible. Proposed OFCCP Regulation, 46 Fed. Reg. 42,968, 42,985 (1981) (to be codified at 41 C.F.R. $\S$ 60-1.21(c)(1)), provides that federal contractors "must not make any distinction based upon sex in . . . fringe benefits." Proposed EEOC Regulation, 46 Fed. Reg. 43,848, 43,851 (1981) (to be codified at 41 C.F.R. $\$ 1620.5(f)$ ), provides: "It shall be unlawful for an employer to have a pension or retirement plan which . . . differentiates in benefits on the basis of sex." Further, another section provides: "Under the expressed terms of the Act, when a prohibited sex-based wage differential has been proved, an employer can come into compliance only by raising the wage rate of the lower paid sex." Id. at 43,852 (to be codified at 41 C.F.R. $\S 1620.15(\mathrm{a}))$.

4542 U.S.C. $\S 2000 \mathrm{e}-2(\mathrm{a})(2)$ (1976). This section provides that it is an unlawful employment practice for an employer "to limit, segregate, or classify his employees or applicants for employment in any way which would deprive or tend to deprive any individual of employment opportunities or otherwise adversely affect his status as an employee, because of such individual's race, color, religion, sex, or national origin." 
pension benefits is much greater than that of life insurance, the net effect on women is likely to be greater than the effect on men. Although the extent of the impact is difficult to quantify, its precise limits are not relevant, for the language of the statute makes it sufficient that a practice "tend[s] to deprive" an employee of employment opportunities. ${ }^{46}$

\section{B. Possible Per Se Illegality of Sex-Distinct Mortality Tables}

Merton C. Bernstein and Lois G. Williams have concluded that "the Equal Pay Act prohibits per se sex discrimination as to wages"47 and that "Title VII proscribes discrimination on the basis of sex per se"48 unless the sex distinction relates to "a bona fide occupational qualification reasonably necessary to the normal operation of that particular business or enterprise." tators, such as the Brilmayer group, ${ }^{50}$ and the Court in Manhart ${ }^{51}$ object to the use of sex-based mortality tables for calculating fringe benefits on the incorrect view that such tables assign group characteristics to individuals rather than weigh individual characteristics that are the same for all members of a given gender. ${ }^{62}$ It is not clear, however, whether Brilmayer and her coauthors believe, as do Bernstein and Williams, that any use of a sex-related factor to determine compensation is per se illegal, even when its nonuse results in invidious discrimination according to an employee's gender. Therefore, it is worthwhile to consider briefly the arguments against considering sex-related measurements as per se illegal.

Mayer G. Freed and Daniel D. Polsby show that the courts have not upheld a strict per se ban on classifications by sex, and their own view is persuasive:

[A]lthough explicit sex classifications are presumptively invalid, they can be justified where there are strong efficiency interests at stake or where there is a broadly shared social norm that requires that men and women be treated differently. The

16 Id. Some commentators, notably Bernstein \& Williams, supra note 10 , at $1212-13$, and supra note 13 , at 1243-44, suggest this point. This issue is discussed further infra part V-A.

17 Bernstein \& Williams, supra note 10 , at 1214.

48 Id. at 1215.

42 U.S.C. § $2000 \mathrm{e}-2(\mathrm{e})(1)$ (1976).

so Supra note 15 , at 508-10.

61435 U.S. at 707-11.

s2 Recall that at this point I assume that gender is associated with and efficiently predicts the probability of death. 
foregoing statement eschews the illusory certainty of the per se rule in favor of a candid recognition that the most that can be hoped for is the identification of the factors relevant to the resolution of sex discrimination claims and the implications of these factors for decision making. ${ }^{53}$

George Rutherglen also concludes that "[t]he existence of such broad and uncertain areas in which sexual classifications are permissible suggests that the appropriate conception of sexual equality is not a version of the color-blind conception of racial equality."

But the most important argument for not applying a per se rule is that its use would work contrary to the intent of the antidiscrimination statutes. As discussed in part II above, consideration of the gender of annuitants and life insureds is necessary to measure both the value of these products to them and the cost to the insurer. Thus, if this factor cannot be used legally, employees will be unfairly treated solely because of their sex..5

ss Freed \& Polsby, supra note 13, at 589-90. They review the cases id. at 592-602.

${ }^{54}$ Rutherglen, supra note 13, at 214-15; see also the cases cited therein, id. at $214 \mathrm{n} .78$.

ss Rutherglen's analysis leads him to a similar conclusion:

To the extent that an anticlassification interpretation of title VII prohibits sexual classifications necessary for equal treatment, it is inconsistent with the doctrine of disproportionate adverse impact; to the extent that a prohibition against sexual classifications results in unequal treatment, it also results in a disproportionate adverse impact.

Id. at 248. He later qualifies this conclusion, stating:

The conception of equality as equal treatment, therefore, must exclude from the determination of equal treatment sex-based classifications that, although economically relevant, are tainted by past discrimination. Specifically, sex-based classifications must be excluded if they would perpetuate past discriminatory practices.

Id. at 250. But, he goes on:

Even assuming that the greater life expectancy of women is the result of past discriminatory practices, for instance, because women have been excluded from hazardous occupations, the use of sex-based actuarial tables does nothing to perpetuate such practices. ...

... If sex is a relevant characteristic and consideration of sex does not perpetuate past discrimination, then fairness requires that it be taken into account. Failure to do* so imposes present costs on those who are denied equal treatment without any prospect of remedying past discrimination or avoiding future discrimination. The effect of Manhart is to deny men equal treatment in pension plans . . . .

Id. at 251 (footnote omitted).

After these and similar conclusions and a careful analysis, Rutherglen inexplicably asserts: "The distinctive defect of the equal-treatment conception of equality is the difficulty of showing that sex is, or is not, nondiscriminatorily relevant to employment decisions." Id. at 254. But in his prior discussion of Manhart, id. at 241-48, he severely and cogently criticizes arguments against the use of sex-distinct actuarial tables, saying:

[P]redictions of life expectancy must take sex into account to achieve the greatest possible accuracy. Scientific studies of life expectancy routinely classify individuals on the 
Finally, the arguments put forth by Brilmayer and her colleagues for treating an employee's sex as a forbidden criterion should be considered. They claim:

Race, color, sex, religion, and national origin share three characteristics that justify the restrictions on their use. First, they are ascriptive and immutable. Second, they have been widely misused throughout history. Third, they are generally irrelevant to employment decisions. ${ }^{58}$

As I hope the following brief analysis will show, treating these characteristics as forbidden criteria would tend to increase the unfair treatment of individuals.

Because individuals have no control over their gender, Brilmayer and her colleagues claim that there is "a special sense of unfairness [in sex discrimination], for the victim can never escape discrimination by her own efforts." mutably associated with one's gender, at least over the period to which the insurance contract applies, as they and I assume at this point in the argument, to disregard life expectancy would be to discriminate unfairly against or in favor of that person. In particular, it is bad enough that, all other things being equal, a man is not likely to live as long as a woman. To ascribe to him a lesser probability of his death than is warranted by the available data and hence, to assign him lower promised annuity payments in exchange for a given present sum, is surely to treat him unfairly. Similarly, to promise a woman a lesser amount in the event of her death than is warranted by her individual life expectancy, based on data that efficiently relate this probability to her gender, would be unfair discrimination. Although the recipients probably would not object to receiving more in annuity payments or death benefits,

basis of sex and routinely reveal sex-based differences. Nor does the scientific literature contain any suggestion that sex can be supplanted in the near future by some more accurate predictor of longevity.

Id. at 243 (citations omitted). This clear and forceful defense of the necessity and efficiency of using sex-distinct actuarial tables is inconsistent with his final conclusion: "The anticlassification conception provides clear guidance to both judges and employers about what the law prohibits and what it does not." Id. at 254. And in the last lines of the article, he says: "The Supreme Court correctly [decided] . . . in Manhart in favor of a rule against sexual classifications. Despite the attractions of a rule of equal treatment, both in general and in Manhart itself, the impracticality of the rule threatens to undermine the very equality it seeks to attain." Id. at 256. It is difficult to understand how the same person could have written both this conclusion and the analysis that preceded it.

se Brilmayer group, supra note 15, at 526-27 (footnotes omitted).

67 Id. at 527 . 
the extra resources must come from somewhere. Unless this allocation of resources to individuals because of their gender is legislatively ordered, it would seem to be contrary to the statutes that mandate equality. Furthermore, the fact that a personal characteristic is immutable makes its use for insurance contracts particularly valuable, for it lessens the problem of moral hazard. Although a person can change life-shortening habits, such as smoking, after purchasing life insurance or an annuity, a person's gender is not susceptible to such facile change. Therefore, the past relationship between an immutable characteristic and mortality can be expected to continue after the contract is written.

The second cited characteristic, wide misuse of the specified classifications throughout history, is clearly true. As a consequence, use of any of them for distinguishing among employees is, and should be, suspect. But as I have argued, the per se prohibition of sex-distinct mortality tables for computing the value of employees' insurance fringe benefits would exacerbate rather than alleviate the misuse of classifications based on sex. ${ }^{58}$

Brilmayer and her coauthors say that the third characteristic, irrelevance, has two implications. One is that "[e]ven when sex is strongly associated with a job qualification, at least some members of both sexes are qualified." 59 This observation, however, is irrelevant to insurance. The sex-related expected mortality of employees is used not to deny them employment, but to calculate the value to them of, and hence their compensation from, fringe benefits. Furthermore, if the "profit-maximizing" employer, as a consequence of having to use a unisex table to calculate annuities, is required to pay more to women simply because they are female, the result will be fewer employment opportunities for women, which would clearly victimize them.

The second implication of the irrelevance characteristic is "a strong tendency to use forbidden criteria because they are convenient and cheap to administer." carelessly accept actual or apparent past relationships between an employee's gender and other factors as the bases for present decisions, lest stereotypes be continued and unfair discrimination be practiced. But as shown in part II above, the cost of administering an insurance program is very relevant. Disregard of these costs,

\footnotetext{
ss See supra notes $42-55$ and accompanying text.

so Brilmayer group, supra note 15 , at 527.

${ }^{60} \mathrm{Id}$. at 528 (footnote omitted).
} 
particularly when they are reliably associated with such individual characteristics as an insured's gender, necessarily must result in invidious treatment of someone. ${ }^{61}$

\section{Race, Religion, and Mortality}

Because of our strong aversion to racial and religious discrimination, many of those who conclude that use of sex-distinct mortality tables can be morally and legally necessary appear at pains to distinguish this position from one that would permit the use of an insured's race or religion. ${ }^{62}$ Some, like Professor Kimball, argue that race is not relevant to the issue of insurance because there is no reliable empirical relationship between race and longevity, at least with respect to annuitants. ${ }^{63}$ Professor Brilmayer and her col-

"In criticizing the five "forbidden criteria," Professor Brilmayer and her colleagues make numerous assertions about the irrelevance of a person's sex to longevity: for example, it "is a crude predictor even for a group," $i d$. at 530, and "much of the association between sex and mortality is spurious," $i d$. at 531 . These empirical evaluations are very important, but they are relevant to the issue of per se prohibition only if they are empirically valid. Evidence on this question that is inconsistent with their assertions is presented infra part IV.

Professor Brilmayer and her coauthors also deal with the argument for necessity in the same section of their article. Id. at 533-35. Most of this material repeats the previous assertions on the unreliability and potential misuse of sex as a predictor of longevity. Two other questionable statements, however, should be evaluated. One is that sex should not be used as a variable because a defense by a discriminator that an employee's productivity is associated with this trait "would be easy to assert and difficult to litigate." Id. at 534. Considering the enormous amount of available data on longevity and the simple relationship under consideration (the risk of death), this argument does not seem relevant to the question at issue. Additionally, their point is correct that "such defenses would violate the fundamental principles of the Act, by permitting employers to penalize, solely because of their sex, individuals for whom the prediction is inaccurate," $i d$., but the reverse is equally correct. If a person's gender does efficiently measure longevity, required use of unisex tables would also appear to violate the Act.

Second, they claim that the efficient use of an insured's gender as a predictor of longevity is, "[a]t most, . . . a special case of the argument that sex discrimination is sometimes economically efficient." Id. at 534-35. This is not so. Invidious discrimination may be desired by those with a taste for it (bigots), but it is not economically efficient. Indeed, as I discuss in part II above, not to use a personal attribute or other type of information efficiently is likely to result in invidious discrimination.

'2 Even Kimball, Reverse Sex Discrimination, supra note 14, only cautiously allows that "race may sometimes be a legitimate classification. . . . One example of appropriate use might be in a narrow health insurance policy covering only sickle cell anemia." Id. at 111 (footnote omitted).

"s To analogize sex and race in discussing mortality is fallacious. Use of race is, for estimation of mortality, wholly indefensible on factual grounds. Use of sex is not only defensible but it reflects as well both common sense and available facts. Sex as a classifier is also relatively easy to use, while race is impossible to use meaningfully for mortality estimation in the real world. 
leagues, however, conclude that race and sex should be treated similarly with respect to insurance benefits. ${ }^{84}$ I must say that I agree with them.

If the goal is avoiding unfair discrimination against individuals with respect to insurance, all traits associated with a person should be used to estimate the risk that the insured-against event will occur to that person. For example, if sickle cell anemia increases the risk of death, and if it is found only in blacks, and if there is no efficient way to determine which particular black individuals have or are likely to get this disease, but it can readily be determined who is black, the additional risk should be accounted for. If this is not done for annuities, blacks would not only have an immutably greater risk of death, but they would not be compensated for this risk. The same conclusion may hold for ailments related to religious or ethnic groups, such as Tay-Sachs disease in Jews. ${ }^{65}$ Of course, with respect to life insurance, if these traits are disregarded, the beneficiaries of the possibly affected people would gain. If, as a matter of social policy, such a benefit is desired, it would seem most equitable to transfer the resources directly out of the general revenues rather than indirectly from other life insureds. ${ }^{88}$ The administrative costs of identifying, assessing, and monitoring these risks, however, must be considered. As a result, in practice, the risk of these diseases will usually be disregarded.

\section{The Data on Gender and Mortality}

To this point, I have assumed that an individual's gender is an efficient predictor of his or her life expectancy and thus must be accounted for in calculating the value to an employee of insurancerelated fringe benefits if invidiously determined compensation is to be avoided. It is tempting to follow Justice Stevens's lead and say simply: "As a class, women live longer than men." were a false statement, the use of sex-distinct mortality tables could result in unfair discrimination according to an employee's gender. And even though Professor Brilmayer and her colleagues

\footnotetext{
Id. at 113 (emphasis in original) (footnotes omitted).

64 Brilmayer group, supra note 15, at 536-39.

${ }^{B B}$ See Rutherglen, supra note 13 , at 205-12, especially $206 \mathrm{n} .43$, for references to scientific works on ethnic diseases.

${ }^{B B}$ As insurers and insureds adjust to these prohibitions, the costs and benefits will tend to be borne and enjoyed by persons with those traits.

67435 U.S. at 704.
} 
claim at the outset that "[o]ur own view of Title VII does not depend on the demographic evidence," ${ }^{, 88}$ they in fact repeatedly make assertions about this evidence that are required for the validity of the conclusions they draw. ${ }^{69}$

The essential question that must be considered now is whether the data on gender-related life expectancy qualify as efficient estimators of the risk of death. An answer to that question should deal with issues such as whether these data are likely to have been contaminated by unfairly stereotyped beliefs about men and women, whether alternative measures of life expectancy could be used that would obviate the need to consider the insured's gender, and whether the use of sex-distinct annuity tables is likely to perpetuate unfair stereotypes and to limit the opportunities for women. Finally, because it is unlikely that these questions can be answered in a completely satisfactory fashion, I present some reasons for believing that unqualified proofs are not necessary for the issue at hand-sex discrimination in annuities.

\section{A. Gender and Life Expectancy}

A characteristic of an insured can usefully indicate the risk of death and hence, the value of an annuity or life insurance policy to an employee, if it efficiently predicts the probability of death. ${ }^{70} \mathrm{Be}$ cause a prediction of a future event is required, data on past relationships are useful only if the relationships found are likely to persist over the period in which the event could occur. For this purpose, the data should relate to the person who is insured; that is, it should be derived from the experiences of similar persons.

os Brilmayer group, supra note 15, at 507.

09 In particular, in discussing and apparently dismissing Kimball's correct and important point that the benefit to an employee is the present value of the expected annuity payments, Reverse Sex Discrimination, supra note 14, at 99-102, Professor Brilmayer and her colleagues state:

This expectancy argument begs the question in a fundamental way. The ultimate issue is precisely whether mortality data may be classified by sex for the purpose of paying annuities-that is, whether sex may be used to predict longevity. No expectancy can be calculated until that question has been answered.

Brilmayer group, supra note 15 , at 512 . In dismissing the argument that sex-distinct tables be allowed as an exception to the ban on disparate treatment, they assert: "Finally, sex is irrelevant to longevity in the Title VII sense: it does not predict longevity in individual cases, and is a crude predictor even for groups." Id. at 530. These assertions are not, in fact, supported by any data presented that are relevant for the present issue, as I show infra part IV-B.

70 See supra part II-B. As defined there, "efficient" refers to the use of information so that the marginal benefits derived from its use are at least equal to its marginal cost. 
The postulated relationship also should have provided useful predictions of life expectancy: the actual and the predicted times of death should be close, compared with alternative predictors. This last point is important, because the most one can do in assessing risk is to compare one set of predictors with alternatives, such as using other variables, throwing dice, consulting oracles, or using a table of random digits. It is preferable that the postulated relationship be grounded in a theory that efficiently predicts the effect of changed circumstances on life expectancy. But this is not necessary if past relationships have been stable and previous predictions accurate.

The use of an insured's gender as a predictor of his or her life expectancy meets all of these criteria well, as the following data indicate. The question at issue concerns annuities for employees of United States companies; therefore, the data presented generally relate to persons who can be members of this set.

1. The Accuracy of Predictions of Mortality Based on Gender. Table 1 shows the ratios of actual to expected deaths by age group of annuitants with individual policies at United States insurance companies over the period 1960 through 1967. Three sex-distinct life expectancy tables that were created with data from different time periods were used to project the expected incidence of death from 1960 through 1967. The projections made with the a1949 Ultimate Tables were almost all more than the actuals, producing ratios that are almost all less than 1.0; decreases in mortality apparently were not sufficiently accounted for. These sex-distinct tables, however, yielded almost the same degree of error overall for females and for males. The 1963 Experience Tables were almost perfectly on the mark for both males and females. The 1971 IAM Tables provided for an underestimate of mortality to adjust for the belief that life expectancies would lengthen; past experience was adjusted to this expectation. Note, though, that the adjustment is virtually the same for males and females. Thus these data show that the expectation models that use sex- and age-classified data are not biased by sex, because they predict well. Considering that, at the annuity-relevant ages (over sixty), the male mortality rate is about twice that of the rate for females, ${ }^{73}$ it is clear that a merged gender (unisex) table would not predict mortality nearly as well.

72 See infra p. 516, Table 2. 
TABLE 1

Ratios of Actual to Expected Deaths Based on Various Annuity Tables; Experience of Insurance Companies on Individual AnnutTies, 1960-1967

\begin{tabular}{|c|c|c|c|c|c|c|}
\hline \multirow[b]{3}{*}{ Age Group } & \multirow{2}{*}{\multicolumn{2}{|c|}{$\begin{array}{c}\frac{\mathrm{a}-1949}{\text { Ultimate Tables }} \\
\end{array}$}} & \multirow{2}{*}{\multicolumn{2}{|c|}{$\frac{1963 \text { Experience }}{\underline{\text { Tables }}}$}} & \multirow{2}{*}{\multicolumn{2}{|c|}{$\frac{1971 \text { IAM }}{\underline{\text { Tables }}}$}} \\
\hline & & & & & & \\
\hline & Male & Female & Male & Female & Male & Female \\
\hline $60-64$ & 1.01 & 1.11 & 1.04 & 1.05 & 1.31 & 1.33 \\
\hline $65-69$ & .95 & .87 & 1.01 & .99 & 1.27 & 1.25 \\
\hline 70-74 & .95 & .86 & 1.01 & 1.00 & 1.27 & 1.27 \\
\hline $75-79$ & .94 & .92 & 1.00 & 1.00 & 1.26 & 1.27 \\
\hline $80-84$ & .95 & .97 & 1.01 & 1.00 & 1.25 & 1.24 \\
\hline $85-89$ & .91 & .98 & 1.00 & .99 & 1.19 & 1.17 \\
\hline $90-94$ & .95 & .98 & 1.00 & 1.01 & 1.14 & 1.16 \\
\hline 95-99 & .98 & .78 & .97 & .97 & 1.08 & 1.08 \\
\hline $60-99$ & .94 & .93 & 1.01 & 1.00 & 1.25 & 1.23 \\
\hline
\end{tabular}

SouncE: Derived from Cherry, The 1971 Individual Annuity Mortality Table, 23 TransacTlows (Soc'y of Actuaries) 475 (1971) (numbers rounded off) (footnotes omitted).

2. Differences in Mortality by Gender Over Time. Further evidence on the usefulness of considering gender and age, and support for the conclusion that sex-distinct annuity tables are useful and, indeed, necessary, are provided by Table 2 . This table gives the ratio of actual male mortality rates to female mortality rates from 1900 through 1975 at ages sixty, sixty-five, seventy, and seventy-five for the United States white population. As it shows, male mortality rates at all relevant ages and time periods are greater than the female rates. The magnitudes are such that, if they are not accounted for and if the relative numbers of females in the group are other than trivial, predicted mortality is likely to differ considerably from actual. ${ }^{72}$

72 The fact that the distributions of mortality rates for males and females of a given age overlap to the extent of about $84 \%$ has been used by some "experts" and advocates to "demonstrate" that "the argument that females live longer than males is a generality that applies to a minority and not the majority." Martin, Gender Discrimination in Pension Plans, 43 J. Risk \& INS. 203, 209 (1976). The "overlap" also gave rise to arguments such as 
TABLE 2

Ratio of Male to Female Mortality Rates at Retirement Ages U.S. White Population, 1900-1975

\begin{tabular}{ccccc}
\hline & \multicolumn{3}{c}{ At Age } \\
\cline { 2 - 5 } Period & $\underline{60}$ & $\underline{65}$ & $\underline{70}$ & $\underline{75}$ \\
\hline $1900-02$ & 1.14 & 1.15 & 1.10 & 1.10 \\
$1909-11$ & 1.19 & 1.16 & 1.10 & 1.12 \\
$1919-21$ & 1.13 & 1.10 & 1.09 & 1.08 \\
$1929-31$ & 1.28 & 1.24 & 1.19 & 1.14 \\
$1939-41$ & 1.49 & 1.39 & 1.29 & 1.21 \\
$1949-51$ & 1.78 & 1.67 & 1.48 & 1.33 \\
$1959-61$ & 2.08 & 1.95 & 1.71 & 1.49 \\
$1969-71$ & 2.19 & 2.17 & 1.96 & 1.70 \\
1972 & 2.19 & 2.15 & 1.98 & 1.73 \\
1973 & 2.14 & 2.19 & 2.03 & 1.73 \\
1974 & 2.09 & 2.17 & 2.02 & 1.74 \\
1975 & 2.07 & 2.18 & 2.04 & 1.78 \\
\hline
\end{tabular}

Source: Derived from Survival After Midlife, 58 Statistical Buld. 2 (Metropolitan Life Ins. Co., July-Aug. 1977).

Note: Data on the total population are not given in this publication although they are almost the same, because $87.4 \%$ of the total United States population is white. See U.S. Bureau of the Census, 1970 Census of Population \& Housing 5 (Summary Vol. 1, Oct. 1971). The nonwhite mortality rates also are similar. See Survival After Midlife Among Nonwhites, 58 Statistical Buld. 10, 11 (Metropolitan Life Ins. Co., Oct. 1977).

the following:

[The use of sex-distinct annuity tables] allows employers to arrange things so that the savings in annuity costs for the 8 percent of the population consisting of excess men who die early are entirely monopolized by men, although 84 percent of all men are in the overlap group.

The extra burdens imposed by the higher annuity costs of 8 percent of the population consisting of excess women who die late are entirely allocated by employers to women, 84 percent of whom are in the overlap group.

Bergmann \& Gray, Equality in Retirement Benefits: The Need for Pension Reform, 8 Crv. Rrs. Dig. 25, 25 (1975).

The fallaciousness of the conclusions drawn from the overlap phenomenon has been explained cogently by several writers, including comments on Martin's article by Hedges, Gender Discrimination in Pension Plans: Comment, 44 J. RIsK \& INs. 141, 143 (1977), and 
Table 2 also shows that the ratio of male to female mortality rates has been generally increasing since 1900 , though it has been fairly stable since the 1950's. For the purpose of assessing the risk of an annuity promise, these data are reasonably stable, for predictions must be made only over a twenty- or twenty-five-year period, the time from an employee's retirement until his or her death.

3. The Influence of Factors Other than the Insured's Gender and Age. It is well known that gender and age are not the only personal characteristics that predict death. As Justice Stevens noted, "a significant part of the longevity differential may be explained by the social fact that men are heavier smokers than women," "7s and "[o]ther social causes, such as drinking or eating habits-perhaps even the lingering effects of past employment discrimination-may also affect the mortality differential." " It would be in the self-interest of insurers to use these and other facts for assessing the risk posed by an insured. Why, then, do they not do so?

The first answer is that they do, where the cost of obtaining and using the information does not exceed the benefits from improved assessments of risk. As Barbara J. Lautzenheiser points out:

In life insurance, the risk being borne by the insurer is the risk of early death. The insurer, then, must guard against the

Myers, Further Comment, id. at 144, 145; see also Johansen, The Inequity of Equality, The ActuARY, June 1977, at 5; Kimball, Reverse Sex Discrimination, supra note 14, at 120-23; King, Men, Women, and Life Annuities, 27 C. \& Unrv. Personnel Assoc. J. 65, 67-72 (1976). These writers point out that an overlap of two distributions is irrelevant for assessing probabilities, unless it can be shown that at some accepted level of error, the two distributions are not significantly different; hence, although they may differ, it is not efficient to distinguish them. This is certainly not the case in most instances for distributions with overlaps of only $84 \%$. Indeed, as Johansen calculates, if each person of a group of 1000 males and 1000 females of age 65 were given a dollar for each year he or she continued to live, "then the total annuity payments to the cohort of 1,000 females over their lifetimes would exceed the payments to the 1,000 males by 23.5 percent. In no way can it be asserted that this excess number of payments is financially inconsequential." Johansen, supra, at 5 . The critics of the "overlap" demonstration also point out that almost exactly the same overlap is found for ages five years apart (which is one reason that actuaries simply "set back" the male mortality table by five years to use as an approximate female table). See Kimball, Reverse Sex Discrimination, supra note 14, at 122-23. It is particularly upsetting to me, as an economist, that Martin, Bergmann, and Gray, who are professors of finance and economics and who should know better, put forth this argument. It also is unfortunate that the Brilmayer group, supra note 15, at 531, repeats it; although they also cite Kimball, id. at n.121, they do not mention his valid critique.

7s 435 U.S. at 709-10.

74 Id. at 710 n.17. 
insured's having knowledge ... that he has not been feeling well, that he has a certain disease, that his family history indicates a certain disease, that he sky dives on Sundays, i.e. knowledge that will put him in a special "extra cost" class. So these characteristics, along with age and sex, are information the insurer needs to know to classify the risk properly. In life insurance, then, selection is done by the insurer. ${ }^{75}$

Consequently, "today most large insurers recognize and underwrite as many as fifteen to twenty-five substandard [that is, "extra cost'] classes, at premium rates in excess of standard rates but based on the anticipated cost of providing the coverage."

With respect to annuities, though, Lautzenheiser asks: "Why, then are not these questions of health, occupation, avocation, etc. as well as questions of age and sex asked when an annuity is issued?"77 She answers by asking rhetorically:

If a person knows he or she has a higher probability of dying because of any of the elements-health, occupation, family history, avocation-would he or she not be unwise to buy an annuity which pays only for long life, not short life? In the case of an annuity, then, self-selection is done by the insured (annuitant) in advance for all the elements except age and sex. Hence those are the only questions that need to be asked by the insurer.

In either case all elements are important; it's just that the insurer relies on the insured to do some of his selection in the case of annuities. ${ }^{78}$

Because of this self-selection for individually purchased annuities and because employment annuities are paid only to people who are well enough to retire, insurers assume that annuitants are likely to live longer than people in general, and the mortality tables take

${ }^{70}$ Lautzenheiser, Sex and the Single Table: Equal Monthly Retirement Income for the Sexes?, 2 Employee Bengrirs J. 8, 38 (1976). Lautzenheiser is Vice President and Actuary of Bankers Life Nebraska.

${ }^{78}$ Bailey group, supra note 10, at 791. The authors describe six of the specialized classifications and point out that, in the early history of risk classification, after it was recognized that without such classifications the insurance schemes failed, "[h]ealth history and general physical condition, sex, occupation, morals, use of alcohol or tobacco, and other matters pertaining to the life style of the applicant were considered in the underwriting of each risk." Id. at 785.

77 Lautzenheiser, supra note 75 , at 38.

${ }^{78} \mathrm{Id}$. 


\section{this expectation into account. ${ }^{79}$}

Other reasons why such important mortality-related factors as smoking, heredity, personality, and places of birth are not considered in estimating the cost for annuitants is that they are either susceptible of misrepresentation by the annuitant, have not been recorded sufficiently for reliable statistics to have been developed, or do not predict well the annuitant's condition at the time the annuity is expected to be paid. For example, annuitants have incentives to claim that they previously smoked heavily; but even if this claim could be verified, how could the confessed smokers be prevented from shaking the habit later? Heredity also is known to be an important determinant of longevity, but how can an insurer verify an annuitant's claim that his or her parents' relatively early deaths were due to causes that are presently or prospectively relevant? This difficulty of verification is even more pronounced for personality. Gender, though, does not present this problem.

4. Theoretical Relationships, Spurious Correlations, and Changing Environmental Conditions. It is a commonplace and correct observation that biological and environmental factors rarely, if ever, can be completely distinguished in studies of human behavior, morbidity, and mortality. Nevertheless, there is reason to believe that a significant portion of the clearly lower mortality

79 See 1 J. GREIDER \& W. BEAdLES, supra note 27, at 296-99 ("death rates at the various ages are generally lower for annuitants than for insured lives and ... different mortality tables are used for computing annuity rates and payments than are used for life insurance purposes"). Note also that the data presented in Table 1 are for all types of policies combined. Actuaries know, however, that people tend to select the types of policies that reflect their estimates of their own life expectancies. For example, in reviewing the data, Cherry, The 1971 Individual Annuity Mortality Table, 23 Transactions (Soc'y of Actuaries) 475, 531 (1971), reports:

As expected, nonrefund immediate annuities exhibit the lowest mortality ratios, 87.6 percent overall for males and 90.0 percent for females. Nonrefund settlement annuities also have lower-than-average mortality ratios [actual to expected], although not as low as under immediate annuities (92.4 percent for males and 98.2 percent for females). Under immediate annuities with a refund period, mortality ratios for males are practically the same under settlement annuities with a refund period, about 102 percent in both cases. For female refund annuities, the mortality ratios are 98.8 percent and 103.2 percent for immediate annuities and settlement annuities, respectively.

A refund annuity provides that "if the total of the payments actually made to the annuitant at the time of his death does not equal or exceed the purchase price he paid for the contract, the difference will be paid to a successor-payee, if living, otherwise to the annuitant's estate." 1 J. Greider \& W. BeAdLES, supra note 27, at 291. An immediate annuity is purchased by the annuitant for himself while a settlement annuity is paid to a beneficiary designated by the insured. Id. at 292, 294. People who have lower expectations of long life are likely to opt for refund annuities, but there is no particular self-selection bias for the immediate versus the settlement annuities. 
rates of females is inherent. One genetic explanation is that the female has two $X$ chromosomes while the male has an $X$ and a $Y$, which is postulated to give the female a better chance to obviate the consequences of a recessive wayward gene in an $X$ chromosome. ${ }^{80}$ Innate differences in the physical make-up of females and males also appear to play an important role in longevity. As Amram Scheinfeld concludes: "under like conditions, females are better adapted to cope with most human afflictions because they are genetically better constructed and have a more efficient chemical system."81 Twelve studies that directly addressed this hypothesis were reviewed by Ingrid Waldron, who somewhat cautiously summarized them as follows: "Genetic factors apparently also contribute to higher male mortality, although the evidence for this is not as strong as commonly has been believed."82 Those studies, however, were related to mortality at all ages, while the present issue concerns only people of retirement age. Therefore, it should be of interest to review a study that directly considered the cause of the mortality differential among males and females of retirement age.

Francis C. Madigan carefully gathered and examined the mortality records from 1900 through 1954 of 9813 Roman Catholic religious Brothers and 32,041 Sisters who were teachers and administrative personnel engaged in educational work. ${ }^{8 s}$ To obtain a homogeneous group of subjects, he excluded "those who have served in foreign missions, those who had been married before entrance into the religious life, the foreign-born, the non-white, and those who had entered into the religious community on or after their twenty-seventh birthday."

Five highly significant sources of differential stress between the sexes had been eliminated: (1) male service in the armed forces; (2) greater male liberty to dissipate; (3) the dissimilar roles of husband and wife; (4) male employment in hazardous and life-shortening occupations; and (5) the employment of

so See A. Scheinfeld, Your Heredity and Environment 217-21 (1965).

31 Id. at 218-19 (emphasis in original).

${ }^{82}$ Waldron, Why Do Women Live Longer Than Men?, 10 Soc. ScI. \& MED. 349, 349 (1976).

${ }^{83}$ Madigan, Are Sex Mortality Differentials Biologically Caused?, 35 MmBAnK MEMoRIAL Fund Q. 202, 206 (1957). The records examined included $98 \%$ of the universe of religious Brothers and $50 \%$ of the universe of Sisters in 1927, the midpoint of the study.

s4 Id. at 204. 
men and women in diverse occupations. ${ }^{85}$

The only possible important nonbiological factors not controlled for were that "the Brothers are more likely to smoke and take an occasional drink," and "the life of the young [up to age forty] Sisters seems to be slightly more stressful."86 Madigan's findings for ages sixty-five and over are summarized below in Table 3, where the ratios of male to female mortality rates, by decade from 1910 through 1949 and 1950 to 1954, and by age group, are given for the Roman Catholic Brothers and Sisters and for the United States white population. In all periods and ages, the ratios in Table 3 show that males experienced higher death rates than females, and in nine of the twelve usable subsets and over the period as a whole, the difference between the sexes for the Roman Catholic sample was greater than for the United States white population. ${ }^{87}$ Madigan thus concluded that biological factors were the chief cause of the superior longevity of the Sisters. ${ }^{88}$

Professor Brilmayer and her coauthors hastily dismiss these findings, arguing that "[b]ecause differences in smoking behavior account for a large portion of the SMD [sex mortality difference] in the general population, Professor Madigan's study is of no probative value." based solely on Madigan's statement that "the Brothers are more likely to smoke." $"$ The male-female differentials he reported cover

ss Id. at 205.

ss Id. at 204.

87 The findings for ages below 65 are similar. The major difference is that mortality rates for Roman Catholic Sisters are greater than those for Roman Catholic Brothers at ages 15 through 44 for the periods before 1939 (with two exceptions). Madigan explains that these exceptionally high death rates among the Sisters were due to tuberculosis. Id. at 21718.

s8 Id. at 217 .

Bo Brilmayer group, supra note 15 , at 550 . Waldron, supra note 82 , at 350 , is more careful, stating that "the higher mortality of the Brothers cannot be attributed solely to genetic causes" (emphasis added).

" Madigan, supra note 83, at 204 (emphasis added). In the lengthy dissertation from which his article was drawn, Madigan does not mention any differences in smoking habits between Brothers and Sisters. F. Madigan, The Differential Mortality of the Sexes, 19001954: Cultural and Biological Factors in the Diverging Life Chances of American Men and Women (1956) (available in the University of North Carolina at Chapel Hill Library). He describes at length the regimented and similar quality of their daily lives, which included "easy access to good medical and dental care; . . . a calm and peaceful regime of daily life, which fixes the amount of time to be given to sleep, to recreation, and to work and prayer; the practice of a life of moderation in eating, drinking, exercise, and generally in all other things; the prudent counsel and direction of a wise and experienced religious superior; and the role behavior expected of the members of the two groups." Id. at 64 . Because the Broth- 


\section{TABLE 3}

Ratio of Male to Female Mortality Rates at Retrement Ages Roman Catholic (R.C.) Teaching and Administrative Brothers and Sisters Compared to U.S. White Population, 1910-1954

\begin{tabular}{llllllll}
\hline \hline & \multicolumn{2}{c}{ Age 65-74 } & \multicolumn{2}{c}{ Age 75-84 } & \multicolumn{2}{c}{85 and over } \\
$\underline{\text { Period }^{\mathrm{a}}}$ & R.C. & U.S. & R.C. & U.S. & R.C. & $\underline{\text { U.S. }}$ \\
\hline $1910-19$ & 1.10 & 1.14 & $2.36^{\mathrm{b}}$ & 1.09 & $\mathrm{c}$ & 1.04 \\
$1920-29$ & 1.52 & 1.17 & 1.75 & 1.10 & $c$ & 1.04 \\
$1930-39$ & 1.30 & 1.28 & 1.45 & 1.15 & $c$ & 1.10 \\
$1940-49$ & 1.26 & 1.44 & 1.19 & 1.22 & $1.18^{\mathrm{b}}$ & 1.15 \\
$1950-54$ & 1.92 & $1.53^{\mathrm{d}}$ & 1.42 & $1.25^{\mathrm{d}}$ & $1.28^{\mathrm{b}}$ & $1.10^{\mathrm{d}}$ \\
$1900-54$ & 1.41 & $1.34^{\mathrm{d}}$ & 1.40 & $1.20^{\mathrm{d}}$ & 1.56 & $1.13^{\mathrm{d}}$ \\
\hline
\end{tabular}

Source: Madigan, Are Sex Mortality Differentials Biologically Caused?, 35 MndanK MrMORIAL FUND Q. 202, 216 (1957).

a United States data are through the end of the decade (e.g., 1910-1920).

b Based on fewer than 50 persons.

c Not available (1900-09 not shown for this reason).

d United States data here are through 1953.

historical periods before deaths from smoking were likely to be important ${ }^{91}$ and over which the higher male death rates nevertheless were found. Furthermore, Robert D. Retherford, who is cited by the Brilmayer group ${ }^{22}$ and Justice Stevens, ${ }^{93}$ presents data suggesting that even if the Brothers smoked as heavily as the male population in general, the life expectancies of males and females reflected in Table 3 would not be changed much. ${ }^{24}$ In short, Madi-

ers and Sisters were predominantly teachers of children, it is unlikely that they would have been permitted to smoke, except perhaps in the time permitted for private recreation. According to the typical daily schedule given by Madigan, id. at 69, this time is unlikely to have exceeded an hour a day.

-1 See Table 3 above; infra note 94.

22 Brilmayer group, supra note 15 , at 533 n.130.

93 435 U.S. at 710 n.17.

94 R. Retherpord, The Changing Sex Difrerential in Mortality 74-79 (1975). The only data on smoking and mortality are from an American Cancer Society study carried out from 1959 to 1964. Retherford gives the following life expectancies at age 37, id. at 75 (table 14) - the only relevant data he presents. For comparison, the most similar data given by Madigan, supra note 83, at 213 (table 1 ), follow as well: 
gan's conclusion that biology is the chief ingredient in female longevity has not been seriously challenged.

Of course, environmental factors also play a large role in determining the higher United States male mortality rates. Waldron reviewed 163 scientific papers and concluded that:

Sex differences in behavior are a more important cause for higher male mortality than are any inherent sex differences in physiology. Furthermore, although sex differences in behavior may be due in part to genetic differences, cross-cultural and developmental studies clearly show that child-rearing practices and cultural factors strongly influence behavioral differences in both children and adults.95

Although it may be desirable to effect the societal changes that would bring about a decrease in male mortality, Waldron admits that the required behavioral modifications "will be difficult to achieve."98 Indeed, if much of this behavior is itself genetic (as the sociobiologists claim $^{97}$ ), it is unlikely to change quickly, if at all. In any event, it seems clear that the generally acknowledged difference between male and female mortality rates, particularly at ages above sixty, is significantly, though not entirely, due to biological and other relatively unchanging factors. Brilmayer and her colleagues are wrong in stating that "[s]ex is also irrelevant in a re-

\begin{tabular}{lccc}
\hline & Females & Males & $\underline{\text { (F/M) }}$ \\
\cline { 2 - 4 } $\begin{array}{l}\text { Retherford (at age 37, 1959-64) } \\
\text { cigarette smokers }\end{array}$ & 41.33 & 35.44 & 1.17 \\
nonsmokers & 42.64 & 39.93 & 1.07 \\
total sample & 42.37 & 37.24 & 1.14 \\
Madigan (at age 35, 1950-54) & & & \\
U.S. white & 40.80 & 35.90 & 1.14 \\
Sisters and Brothers & 43.25 & 37.61 & 1.15
\end{tabular}

If the Sisters are considered to be like Retherford's nonsmoking females, and the Brothers like Retherford's total male sample, the F/M ratio would be $42.64 / 37.24$, or 1.15 . Also, Retherford shows that relatively heavy cigarette smoking (which he believes is mainly responsible for greater mortality) did not begin until the 1930's: consumption per capita went from 611 in 1920 to 1365 in 1930, and then increased again to 3322 in 1950 . Retherford, supra, at 72. Smoking by Brothers in these years is unlikely to have affected the death rates of most of Madigan's sample, because it covers the period 1900-54.

${ }^{93}$ Waldron, supra note 82 , at 358 (footnote omitted).

Id.

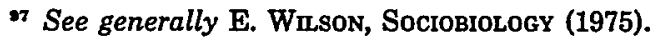


lated sense: much of the association between sex and mortality is spurious."

For the present issue of estimating the value of retirement annuities to employees, whether environmental or biological factors are responsible for the acknowledged difference in mortality by gender is relevant only if those factors affect the accuracy of mortality predictions. As the data presented above and the voluminous actuarial science literature show, knowledge of an annuitant's gender permits a much more accurate assessment of the risk of that person's death than is provided by models that omit this variable. Though the measured past relationships may change (for example, as more women smoke), the data presently available indicate that the disparity between male and female mortality rates has widened during this century and is too large to be ignored.99 Furthermore, the available evidence indicates that the increasing participation of women in the labor force is unlikely to affect greatly their life expectancy. In particular, even Professor Brilmayer and her coauthors note that "[o]ne study by TIAA-CREF reports that there is no difference in the mortality experience of its primary female annuitants (covered working women) and its secondary female annuitants (the wives of working men)."100 Their following objection that "this insurance pool consists of upper-level white-collar workers whose overall mortality is likely to be low because of their socioeconomic status, which is shared by their immediate families,"101 actually reinforces the point. The only important difference between the two groups of women with the same mortality experience is that the primary annuitants worked at colleges and universities while the secondary annuitants did not; thus there is no socioeconomic differential between the two groups. Professor Brilmayer and her colleagues also cite "[a] study of Railroad Retirement Board beneficiaries [that] shows [in fact] 'slightly longer life expectancies at all ages 60 and over for female retired employees than for wives and widows of male retired employees." "102 Although it may be true, as Brilmayer and her colleagues say, that

${ }^{98}$ Brilmayer group, supra note 15 , at 531.

92 In setting annuity payments, insurers tend to use tables that reflect the most recently available data that pertain to the people insured. Hence, as relationships change, so do the calculated risks and the periodic payments promised at the time the payments begin.

${ }_{100}$ Brilmayer group, supra note 15, at 557 n.276 (citing R. Duncan, TIAA FEmale MorTALITY EXPERIENCE 1965-70 (1972) (on file with The University of Chicago Law Review)).

101 Brilmayer group, supra note 15, at 557 n.276.

${ }^{102}$ Id. (quoting R. DuncaN, supra note 100 , at 1 ). 
"[i]n this pool, women workers may have been disproportionately white collar, so that they did not necessarily share the socioeconomic status of male coworkers and their wives,"10s this concern does not invalidate the findings that the greater longevity of women does not appear to be adversely affected because they work outside the home.

Finally, one might ask whether it is equitable to treat a specific person as simply a woman or man of a given age. The answer can be found by considering the alternative-what if a person's gender is not considered? In that event, the risk of any man's death will be estimated as being equal to the risk of the death of any woman of the same age. Hence, given our present state of knowledge, ignoring a person's gender necessarily results in an incorrect assessment of the risk and unfair discrimination against that person.

\section{B. An Evaluation of the Brilmayer Group's Demographic Evidence}

Professor Brilmayer and her coauthors devote over a third of their article to showing that "sex turns out to be a spurious, weak, and unstable predictor of mortality,"104 and their "findings" already have been given popular currency. ${ }^{105}$ In fact, as the following analysis shows, this important part of their paper is comprised primarily of nonsequiturs or incorrect statements.

1. Nonsequiturs. Most of the Brilmayer group's presentation is devoted to demonstrating the inaccuracy of Professor Kimball's sweeping and unnecessary generalization that "[w]omen have better mortality experience than do men, at all ages from conception on, at all times during this century, in almost all countries."108 Ac-

\footnotetext{
20s Brilmayer group, supra note 15 , at 557 n.276.

204 Id. at 559.

108 For example:
}

A recent study carried out by four University of Chicago researchers, and reported in

The University of Chicago Law Review, charges that mortality tables based on sex fail to predict life expectancy accurately and are no more reliable than separate tables based on race or other factors that have been discarded over the years.

Fenske, Unisex Mortality Tables: The Battle Lines are Drawn, 81 Best's REv. 12, 98 (Life/ Health Ins. ed. April 1981). Of course, Brilmayer and her colleagues are not responsible for inaccurate descriptions of their work: in particular, they did not examine the predictive ability of sex-distinct as compared to unisex tables or of tables based on "factors that have been discarded over the years." Id.

${ }^{106}$ Kimball, Reverse Sex Discrimination, supra note 14, at 113 (emphasis in original) (footnote omitted). 
tually, for the issue of employee retirement annuities, only relatively recent data for United States workers of retirement age are relevant, and so Kimball's assertion sets up a straw man. In particular, the data the Brilmayer group presents ${ }^{107}$ to attack this argument about a universal, biological female advantage are relevant only insofar as the material shows that the greater life expectancy of female annuitants is not entirely due to inherent biological factors. Any implication that such data show the unreliability of SMDs for United States retirees is simply a nonsequitur.

2. Misstatements. Professor Brilmayer and her colleagues argue that SMDs are too unstable to use for predictive purposes, relying on evidence that "[i]n the United States, within the adult life of a single annuitant, the SMD measured by the expectation of life at birth increased from 1.0 year in 1920 to 7.7 years in 1970; the SMD at age 65 increased proportionately."108 But the relevant time period for measuring the sex mortality difference between male and female annuitants is the period between retirement and death. Within this period of from 15 to 25 years, the SMD has not varied as greatly. The expected life remaining at age 65 was estimated in 1975 to be 18.1 years for females and 13.7 years for males. ${ }^{108}$ In 1959-61, life expectancies at age 65 were estimated to be 15.9 years for females and 13.0 years for males, and in 1949-51, the corresponding estimates were 15.0 and 12.8 years. ${ }^{110}$ Thus, the retirement age SMDs have changed only 2.2 years over the past 25 years. ${ }^{111}$ The evidence relied on by Brilmayer and her colleagues misstates the historical change in relevant SMDs.

A more important error is one of omission. Professor Brilmayer and her colleagues purport to discuss "The Instability of SMDs,"112 but relevant data are not presented that speak to the essential question of whether sex-distinct tables yield more accurate predictions of life expectancy than unisex tables.

Some indication of the relative stability of the SMDs can be drawn from Table 4, which I prepared from readily available data. The table gives changes in life expectancies at age sixty-five for the

${ }^{107}$ Brilmayer group, supra note 15 , at 542-46.

${ }_{108}$ Id. at 552 (footnotes omitted).

${ }^{208}$ Survival After Midlife, 58 Statistical Bull. 2 (Metropolitan Life Ins. Co., JulyAug. 1977) (representing life expectancies of American white population).

$110 \mathrm{Id}$.

$111(18.1-13.7)-(15.0-12.8)=2.2$. For further evidence on the stability of SMDs, see infra p. 527, Table 4.

112 Brilmayer group, supra note 15 , at 551 . 
total white population, which, if females and males were equally weighted, would be the unisex life expectancy, and for females, males, and the SMD. The changes between decades from 1900 through 1971 and the cumulative changes presented show that the changes in SMDs were both small in absolute amount and, after 1921, always increasing by about the same amount per decade, which is more important, for the problem is to predict changes. In comparison, the changes in the total, the male, and the female life expectancies are either somewhat greater or more variable. If Brilmayer and her colleagues consider the amount of SMD instability too great, then they should be as opposed to actuaries making any changes in life expectancies as they are to actuaries recognizing the different life expectancies of women and men.

TABLE 4

Changes in Life Expectancies in Years at Age 65, U.S. White Population, by Decade, 1900-71: Total, Female, Male, and SMD

\begin{tabular}{|c|c|c|c|c|c|c|c|c|}
\hline \multirow[b]{2}{*}{ Period } & \multicolumn{4}{|c|}{ Decade Change } & \multicolumn{4}{|c|}{ Cumulative Change } \\
\hline & Total & Female & Male & SMD & Total & Female & Male & SMD \\
\hline $1900-02-1909-11$ & -0.2 & -0.2 & -0.2 & 0.0 & & & & \\
\hline $1909-11-1919-21$ & 0.8 & 0.7 & 0.9 & -0.2 & 0.6 & 0.5 & 0.7 & -0.2 \\
\hline $1919-21$ - 1929-31 & -0.15 & 0.1 & -0.4 & 0.5 & 0.45 & 0.6 & 0.3 & 0.3 \\
\hline $1929-31-1939-41$ & 0.55 & 0.8 & 0.3 & 0.5 & 1.0 & 1.4 & 0.6 & 0.8 \\
\hline $1939-41-1949-51$ & 1.05 & 1.4 & 0.7 & 0.7 & 2.05 & 2.8 & 1.3 & 1.5 \\
\hline $1949-51$ - 1959-61 & 0.55 & 0.9 & 0.2 & 0.7 & 2.6 & 3.7 & 1.5 & 2.2 \\
\hline $1959-61-1969-71$ & 0.5 & 1.0 & 0.0 & 1.0 & 3.1 & 4.7 & 1.5 & 3.2 \\
\hline
\end{tabular}

Source: Derived from Survival After Midlife, 58 Statistical. Buld. 2 (Metropolitan Life Ins. Co., July-Aug. 1977).

a Sex Mortality Difference $=$ Female minus Male.

The Brilmayer group's suggestion is that "it is possible that the women on whom the annuity tables are based were an elite group whose greater longevity has temporarily exaggerated the SMD in industry tables."113 The authors speculate that as more women become employed, and as female annuitants from less elite 
classes mature, the SMD will shrink. The authors cite as authority here, however, the Duncan and Railroad Retirement Board studies, ${ }^{114}$ which in fact report almost no difference between women who work in and out of the home. ${ }^{115}$

Discussing the "Implications of the Demographic Analysis,"116 Brilmayer and her colleagues repeat the misstatement discussed above: "Whatever the causes of differential male and female life expectancy, the fact that is most damaging to proponents of segregated tables is that SMDs change rapidly."117 The data presented in Tables $1,2,3$, and 4 refute this conclusion, and the Brilmayer group has not presented relevant data that indicate otherwise. The authors conclude further that "the magnitude of potential errors is enormous in proportion to the difference being predicted."118 They present no data relevant to retirement-age SMDs, however, and the almost exact equivalence of actual and predicted deaths presented in Table 1 is evidence against their assertion. ${ }^{119}$ Furthermore, they fail to consider why insurers who persist in using sexdistinct mortality tables that yield enormous errors have not gone broke.

Finally, in the earlier parts of their article, Professor Brilmayer and her colleagues make assertions on which they rest important aspects of their argument. The authors claim that "knowing a person's sex tells very little about when he will die";120 that "there is no reason to expect sex differences among current insureds to match those reflected in the tables";121 that "[t]he use of sex as a predictor of longevity would be improper even if it were

124 Id. n.276. The footnote includes the following observation, the relevance of which eludes me: "Data on individual life insurance holders show little difference in SMD between policy holders and the general population."

${ }_{115}$ See supra notes 100-03 and accompanying text.

136 Brilmayer group, supra note 15, at 558.

117 Id.

118 Id. at 559 (footnote omitted).

110 Laycock \& Sullivan, supra note 15, at 227, in their response to Kimball, repeat: "But sex mortality differences have not been stable even for three decades in this century in the United States" (footnote omitted). Their citation is to 2 U.S. DEP'T OF HEW, Pubuic Health Service, National Center por Health Statistics, Vital Statistics of the United STATES $\$ 5$ Life Tables, at 5-15 (1977). This table shows the following difference in "Average Length of Life in Years" between males and females (total) from the last year given, 1976, by decades: $1976-7.7 ; 1966-7.1 ; 1956-6.2 ; 1946-5.0$; and $1936-4.0$. (The earliest year given is 1929). The year-to-year change, however, is gradual and slight. See supra p. 527, Table 4. Although these numbers change, they hardly should be described as "unstable."

120 Brilmayer group, supra note 15 , at 531.

${ }^{121}$ Id. (footnote omitted). 
the only available predictor: sex would still be immutable, subject to abuse, and a weak predictor"; ${ }^{122}$ and that "[r]egardless of its causes, the association between sex and mortality is weak and unstable."123 Not only do the data they later present not support these assertions but, as the material presented above shows, the assertions are incorrect:

\section{The Market Solution to the Choice of Relevant Predictors of Longevity}

One additional concern should be addressed. Considering the long and shameful history of discrimination against women, how can we be assured that insurers do not consider an insured's gender to the exclusion of other, more relevant factors because of conscious or unwitting bias against females? And is there reason to fear that continued use of sex-distinct mortality tables will reinforce sexual stereotypes? I believe that the workings of a competitive market for insurance provide satisfactory answers to these questions. These are discussed with respect to the historical evidence of insurers' incentives to use sex-distinct tables, the effect on insurers of not using all relevant factors, and the self-interest of employers and employees.

1. The Incentive of Insurers to Use Sex-Distinct Tables-The Historical Evidence. There is no reason to expect insurers consciously to use any variables other than those that provide efficient estimates of risk. Although some people, including those working for or as insurers, may have "a taste for discrimination,"124 this preference for discriminating against women rarely is satisfied by refusing to take their money, particularly when the biased person need not be in contact with the object of his or her dislike. The only counterargument that I can think of requires effective collusion by all or most insurers to charge women more for insurance. Considering the widespread existence of state laws and regulations that prohibit "unfair discrimination between persons of the same class," ${ }^{2125}$ such collusion would be extremely difficult, even if all the

122 Id. at 534 .

123 Id. at 539 .

124 For an excellent economic analysis of peoples' preferences to avoid association with members of particular groups, see G. Becker, Thr Economics of Discrimination 13-17 (2d ed. 1971).

${ }^{125}$ See Bailey group, supra note 10, at 793. State legislative and regulatory actions are outlined $i d$. at 793-804. 
insurers could agree and could police their agreement. Furthermore, the feared collusion is inconsistent with the actual practice of charging females less than similarly situated males for life insurance, which accounts for a much larger portion of the insurance business than do annuities. ${ }^{126}$

The historical record with respect to the insurance of women is also instructive. Coverage and rates charged to females changed in response to changing experience, which is not consistent with a belief that the rates were imposed in accordance with tastes and opportunities for discrimination. Women were first offered life insurance by Equitable of England in 1762, but for an extra premium. ${ }^{127}$ Following the general population studies in France, Sweden, and Switzerland that showed lower female mortality rates, the English companies dropped the surcharge. But a joint survey in 1893 of their experience found higher female death rates, and the extra premium was restored. An explanation for the unexpectedly higher mortality among insured females was revealed by a United States study of 400,000 female life and annuity policyholders insured between 1885 and 1908. Compared to the expected death rates, the following actual rates were experienced for subgroups of women: spinsters, $81 \%$; widows and divorcees, $105 \%$; and married women, $119 \% .{ }^{128}$ The effects of adverse selection and moral hazard were clear: "When unmarried women bought for themselves, endowments especially, they lived to collect. When married women had insurance bought for them for others to collect, others did just that-they collected."129 Thereafter, insurers attempted to take the self-interest of the insureds and beneficiaries into account, particularly when the policies were purchased by the beneficiaries. Estimates of the risk of death were based on more extensive and detailed statistical studies that considered the gender of insureds, because experience had shown that this was a determinant of life expectancy. There is no evidence indicating that the identification of gender as a determinant was related to any prevailing stereotypes or other prejudices.

2. The Effect on Insurers of Not Using All Relevant Factors. Let us assume, though, that insurers tend to use the insured's gen-

128 G. Bishop, Capital Formation Through Life Insurance 43 (1976). In 1974, life insurance premiums paid to American life insurance companies were $\$ 278$ billion, compared with $\$ 7.7$ billion for annuity considerations.

127 H. Dingman, Risk Appraisal 173-74 (2d ed. 1954).

128 Id. at 174.

129 Id. 
der as a determinant because of unwitting bias or unthinking conformity to past, no longer valid, practices. ${ }^{130}$ The question is then whether Justice Stevens was correct with respect to insurance when he asserted that "[p]ractices that classify employees in terms of religion, race, or sex tend to preserve traditional assumptions about groups rather than thoughtful scrutiny of individuals."131 If he were correct, insurers would be thoughtlessly giving up wealth because they would be failing to recognize the benefits of using more efficient predictors of life expectancy, and those who altered their behavior appropriately would benefit at the expense of the others. If, as Justice Stevens suggests, "a significant part of the longevity differential may be explained by the social fact that men are heavier smokers than women,"132 and if this factor can be utilized efficiently, ${ }^{133}$ only insurers who preferred losses to wealth would ignore it.

3. The Self-Interest of Employers and Employees. Even if insurers generally are unconcerned with changes in their wealth, the antidiscrimination statutes and the self-interest of employees in obtaining a given level of annuity payments and service for the least expenditure will prompt insurers to use information about insureds' life expectancies efficiently. Employers might want to pay women less than men if the supply of women exceeds that of men, all other things being equal, or if all employers have a taste for discrimination. As discussed above, however, the employer could not legally follow this practice if the benefits from a retirement plan were correctly assessed, using sex-distinct mortality tables. ${ }^{134}$ If employers use pension contribution plans that define the contri-

${ }_{130}$ Professor Brilmayer and her colleagues, supra note 15, apparently believe this to be the case, though they offer nothing to support their belief. Rather, they simply state a truism-"The statement that some particular person is expected to live some certain number of years is dependent on a prior decision about how to classify that person"-implying that the decision is random or biased. Id. at 512 (footnote omitted). They then provide an example to show that the life expectancy at birth of people born in South Carolina differs from that of the United States' population. Id. at 512-13. Aside from the lack of relevance of the particular statistics presented (they should have reported life expectancy for retirees and compared the data on males with data on females rather than with data on all persons), they do not consider the reasons that insurers do not use place of birth for annuities. It is not sufficient for them simply to show that alternative variables yield different mortality rates; they must show that the alternatives yield efficient predictors or, at the least, more accurate predictors.

132435 U.S. at 709.

${ }^{132}$ Id. at 709-10 (footnote omitted).

133 See supra part II-B.

134 See supra part III-A. 
butions to be made, but that permit their employees to purchase their own individual annuity contracts under an arrangement administered on a group basis (such as the TIAA-CREF plan used by higher educational institutions), the employees have a considerable incentive to get the insurers to estimate life expectancies efficiently. Even if a plan is used in which benefits, rather than contributions, are set by some formula, the magnitude of pension benefits is such that employees have a similar incentive to get the most for what is, in fact, their money. ${ }^{135}$

\section{ImpLICATIONS of Manhart}

In considering the possible effects on pension structures of a legal prohibition against the use of sex-distinct mortality tables, three situations are distinguishable: Manhart is limited only to direct, employer-operated pension plans; the decision is extended to insurance companies (such as TIAA-CREF) that provide annuities to employees; or the prohibition is extended to all annuities if purchased by an employee in the open market with employer-provided funds.

\section{A. Implications for Employer-Operated Pension Plans}

Some commentators, particularly Bernstein and Williams, ${ }^{138}$ express concern that prohibiting the use of sex-based mortality tables will increase the costs of employing females, thereby giving

135 Professor Brilmayer and her colleagues, supra note 15 , at $531 \mathrm{n} .125$, dismiss the effectiveness of market competition as follows: "the market has not even eliminated the most blatant form of discrimination, the use of segregated tables for annuities and integrated tables for life insurance." Sex-distinct mortality tables are universally used for life insurance, however. The authors must be referring to employee group life insurance, where the premiums charged indirectly to the employee do not reflect the employee's age or gender, probably because the differences in amounts are not sufficient to warrant the administrative costs. But insurers charge employers on the bases of the ages and genders of the actually insured employees. Thus, with respect to employer-sponsored individual plans, the Society of Actuaries states: "Virtually all major insurance companies charge lower life insurance premiums for females than for males." Brief for the Society of Actuaries and the American Academy of Actuaries as Amici Curiae at 25, City of Los Angeles v. Manhart, 435 U.S. 702 (1978) [hereinafter cited as Actuaries' Brief]. Professor Brilmayer and her colleagues continue: "Such market failures are not surprising. Competition is dulled because it is enormously difficult for consumers to compare terms, or even the prices, of annuity and life insurance contracts." Brilmayer group, supra note 15, at 531 n.125. But whether or not consumers do competitive shopping, all insurance companies quote lower life insurance and higher annuity rates for females at any given age, with some additional variation for other factors, such as occupation.

${ }^{136}$ Supra note 10, at 1212-13; supra note 13, at 1243-44. 
employers a strong incentive to discriminate against them in hiring. Consequently, they propose extending the prohibition to annuities generally. Before analyzing this proposal, ${ }^{137}$ I consider the argument that the impact of unisex mortality tables on employeroperated plans, and therefore, on female employment, will be slight.

Perhaps because she is an economist, Sydney J. Key provides the most complete analysis of the implications of using merged tables. She claims that "[w]hile in theory, if all other things were equal, the extra employer expense associated with greater female longevity could become an incentive not to hire women, there are several empirical reasons why this seems unlikely to occur."138 One is that the extra expense is not easily discerned, because "the sex composition of the work force is far from being the only or even one of the more important factors in pension plan funding,"139 and the change made by the insurer is "an unallocated sum that is not broken down by age or sex characteristics of the work force."140 In support of these descriptive statements, Key refers only to a note in the Manhart amici curiae brief of the Society of Actuaries and the American College of Actuaries, which merely states that in defined-benefit plans

it is not necessary, as it is under a defined contribution plan, to establish individual accounts or to make contributions for individual employees, so that the question of whether equal contributions are being made for male and female employees, while an appropriate one to ask, does not have as evident an answer. ${ }^{141}$

But on the same page, the brief notes:

[A]ctuaries must be able to continue to take the sex of employees into account in connection with their determination of what probable costs must be borne by the employers under [defined-benefit] plans. .... In determining what contributions should be made [by employers], the actuary must take account of the expected experience concerning mortality, disa-

${ }_{137}$ See infra part V-C.

1so Key, supra note 13 , at 17-18.

$130 \mathrm{Id}$. at 18.

140 Id. at 19 (footnote omitted).

161 Actuaries' Brief, supra note 135, at 19 n.16. See also 1 J. Greider \& W. Beadles, supra note 27 , at $356-61$. 
bility, turnover, salary increases and other factors which studies have shown differ by sex. ${ }^{142}$

Thus, the extra expense caused by paying female annuitants under a unisex mortality table in a defined-benefits plan will be easily discernible by employers.

In defined-contribution plans, amounts are contributed to the individual account of each employee, and individual costs are of course easily recognized. At present, "every insurance company offers to provide annuities in amounts that are different for men and women if an identical single purchase payment is made."148 If this practice is considered to be illegal, the employer will have to contribute more for women than for similarly situated men. Hence, under either type of plan, the employer forced to use a unisex mortality table must compensate women by greater amounts than men; Key's notion that the added payments to females will not be flagged is thus not supportable.

Key gives two other reasons for expecting that the greater retirement expense of hiring women will not act as an employment disincentive. First, she argues that "the fact that female employees generally have higher turnover rates than male employees may, to some extent, offset the cost to the employer associated with extra female longevity." 144 Of course, this is relevant only where the pension benefits have delayed vesting. But even in delayed-vesting plans, these factors already are taken into account. ${ }^{145}$ Second, Key argues that "[o]ver time the employer may be able to shift part or all of the cost of extra female longevity to all employees either through smaller increases in pension benefits or smaller increases in net wages."148 Consequently, she continues, compensation to males in predominantly male work forces will be higher than compensation to males in mixed work forces, and men will have an incentive to move into predominantly male and out of predominantly female work forces. But, she concludes, this type of movement is unlikely to be empirically important. She may be right or wrong-no studies are cited. But if labor markets are not rigid and

142 Actuaries' Brief, supra note 135, at 19 (footnote omitted).

143 Id. at 25.

144 Key, supra note 13 , at 18 (footnote omitted).

14 Actuaries' Brief, supra note 135, at 19 n.16. If the probability that female, as compared with male, employees will not obtain vested rights to pensions is not considered, however, Key is correct in pointing to this as a mitigating factor.

$148 \mathrm{Key}$, supra note 13 , at 19. 
markets are competitive, the usual economic analysis concludes that the cost will be borne by the companies that are unable to avoid the law by such tactics as attracting predominantly male work forces or not offering retirement benefits. If these assumptions do not hold, the cost will be borne by male employees, investors, consumers, and unemployed females. In addition, there is a dead-weight loss to society because resources are not employed in their marginally most productive uses.

Key considers other possible reactions of male employees to be more important. Though they might not change jobs, she says, male employees may choose the option of receiving a lump sum on retirement, or employers with predominantly male workers may change annuity plans to achieve the same result. Thus, "although for any given benefit plan the mortality experience of males and females would be pooled, in practice the relevant mortality experience for a given option or plan would reflect a predominantly female group."147 She concludes, though, that male employees are unlikely to opt for lump sum payments if they cannot buy annuities, because of the risk they would have to assume. ${ }^{148} \mathrm{Key}$ also dismisses the option of switching to an insurance company that uses sex-distinct tables because of "the high transactions cost associated with switching."149 But she does not consider the incentives to insurance companies of standardizing such switches for a large group of male employees, perhaps through their union, fraternal, or professional association, thereby reducing the transactions cost below the benefit achieved by switching. Consequently, I find her conclusion that female employment possibilities will not be adversely affected to be neither empirically nor analytically supported, unless the prohibition is nullified in practice.

Assuming that the prohibition is effective, some other groups not mentioned by Key are likely to be disadvantaged. The Manhart Court did not "call into question the insurance industry practice of considering the composition of an employer's work force in determining the probable cost of a retirement ... plan."150 Consequently, employers with a predominantly female work force will have an incentive to establish defined-contribution plans with im-

147 Id. at 21.

148 She also could have mentioned the adverse tax consequences of a cash payout. See I.R.C. $\$ 402(\mathrm{e})$ (1976 \& West Supp. 1981).

10 Key, supra note 13 , at 22.

160435 U.S. at 718 (footnote omitted). 
mediate vesting, in which event insurance companies will provide annuities based on sex-distinct female tables, or forgo providing pensions altogether. Both possibilities are socially costly, because employers did not choose their present plans randomly, but for a purpose explainable by such factors as the preferences of their employees and the characteristics of their industries. Those employees who prefer present cash payments to future retirement benefits-for example, young people-will benefit from forgoing pensions but not from the use of female mortality tables.

\section{B. Implications of Extending Manhart to Insurance Companies that Provide Individual Annuities to Employees (TIAA-CREF Type of Plan)}

Presently, litigants in a number of lawsuits are attempting to have the pension plans offered by TIAA-CREF, the nonprofit association that provides pension and insurance services to employees of higher educational institutions, brought under Manhart. They base their suits on the argument that the insurer is an agent of the educational institutions with which it is associated, and thus is as subject as any employer to the decision..$^{151}$ If they are successful, TIAA-CREF would be forbidden to use sex-distinct tables for calculating annuities. The consequences for individual annuitants can be seen with the aid of the calculations presented in Table 5. For this illustration the 1975 life expectancies of a female and a male aged 65 (18.1 and 13.7 years) were used, $\$ 100,000$ was assumed to be the amount in each account, and the retirement fund was assumed to yield from $2 \%$ to $10 \%$ per year. As the table shows, the higher the yield, the greater the annual payment amount, and the less the difference between the expected single-sex female and male payments (because the present value of an amount promised a longer time in the future is less). Also assumed is a $\mathbf{5 0 - 5 0 ~ m i x ~ o f ~}$ female and male retirees, each of whom elects a life annuity with no benefits to beneficiaries. The table shows that a 50-50 merged gender (unisex) table would reduce the man's $\$ 100,000$ investment by between $\$ 11,802$ and $\$ 5,984$ (or his annual pension by from $11.8 \%$ to $6.0 \%$ ) and increase the woman's by the same amount and percentages. If the yields or life expectancies were greater, the effect of using a merged-gender table would decrease, and vice versa.

152 See cases cited supra note 7. For a clear statement of this position, see Van Alstyne, supra note 39 , at $150-55$. 
Many employees elect to have the payments made to them or to their survivor, whoever lives longer. ${ }^{162}$ In this event, the longer expected life of the two and the terms of the contract determine how much is promised. But if the annuitant is, say, a male and his wife is 4.4 years his junior, the life expectancy assumed in Table 5 is the same, and the calculations shown are not affected by a joint option.

\section{TABLE 5}

Erfect of 50-50 Merged Gender Table on Expected Annual Payments and Present Values of $\$ 100,000$ Investment by Male and Female Annutant

\begin{tabular}{|c|c|c|c|c|c|}
\hline & \multicolumn{5}{|c|}{ Net Yield on Investment } \\
\hline & $2 \%$ & $4 \%$ & $6 \%$ & $8 \%$ & $10 \%$ \\
\hline $\begin{array}{l}\text { Female Expected Annual } \\
\text { Payments (life } \\
\text { expectancy }=18.1 \text { years) a }\end{array}$ & $\$ 6,640$ & $\$ 7,869$ & $\$ 9,207$ & $\$ 10,643$ & $\$ 12,168$ \\
\hline $\begin{array}{l}\text { Male Expected Annual } \\
\text { Payments (life } \\
\text { expectancy }=13.7 \text { years) a }\end{array}$ & $\$ 8,417$ & $\$ 9,623$ & $\$ 10,911$ & $\$ 12,278$ & $\$ 13,717$ \\
\hline Merged $50-50^{b}$ & $\$ 7,423$ & $\$ 8,658$ & $\$ 9,987$ & $\$ 11,403$ & $\$ 12,896$ \\
\hline $\begin{array}{l}\text { Differences: } \\
\text { Merged minus female } \\
\text { Merged minus male }\end{array}$ & $\begin{array}{r}\$ 783 \\
-\$ 994\end{array}$ & $\begin{array}{r}\$ 789 \\
-\$ 965\end{array}$ & $\begin{array}{r}\$ 780 \\
-\$ 924\end{array}$ & $\begin{array}{r}\$ 760 \\
-\$ 875\end{array}$ & $\begin{array}{r}\$ 728 \\
-\$ 821\end{array}$ \\
\hline $\begin{array}{l}\text { Increase in female and } \\
\text { decrease in male } \\
\text { investment (present values) }\end{array}$ & $\$ 11,802$ & $\$ 10,027$ & $\$ 8,470$ & $\$ 7,134$ & $\$ 5,984$ \\
\hline
\end{tabular}

Faced with losses of expected wealth and income of the magnitudes given in Table 5, it seems likely that many male employees of higher educational institutions (and similarly affected organizations) and their female survivors, if sufficiently younger than their husbands, would attempt to find a better pension system. Insurance companies would have an incentive to offer retirement plans

132 Among TIAA-CREF's annuitants, $66 \%$ of the males and $18 \%$ of the females elected joint and full, two-thirds, or half to survivor after the annuitant's death. 
to male-dominated institutions, thereby taking advantage of the entirely legal practice of considering the sexual composition of a group in calculating the probable cost of a retirement plan. ${ }^{153}$ For example, male-dominated Massachusetts Institute of Technology might choose to have its own plan, perhaps restricted to teaching personnel, while female-dominated Barnard College would not find this option appealing. ${ }^{154}$ Similarly, an association of tenured economics professors or licensed engineers might be formed and offer a retirement plan that would be open to its members. Women would not be barred from such an organization, although, as it happens, relatively few women are tenured economics professors or licensed engineers. If members of these male-dominated institutions and professions did not think of taking such actions to avoid the effects of a merged-gender table, it seems likely that some insurer would see the profit opportunities and, in effect, do the organizing for them.

If higher educational institutions required their employees to stay with TIAA-CREF, which offers considerable advantages of portability, low administrative expenses, and familiarity, some could still benefit by asking to use a merged-gender table that reflected the institution's actual female-male mix if this resulted in higher payments to the employees. If this occurred, TIAA-CREF would have to have a separate account for each institution at which each participant had worked, raising costs and reducing portability. As a consequence, some institutions might find it desirable to give the retirement amounts to the employees, who then could purchase annuities directly or use the funds for other investments or present consumption. ${ }^{155}$ The individuals would gain freedom of choice, but the institution would accept the risk that some elderly employees might dissipate their savings and be in want or find it difficult to retire.

The net effect of these changes would likely be greater freedom for some individuals but greater risk for the institutions, higher retirement costs for most, and higher benefits to some women, particularly those with female survivors, but not to those who are at least 4.4 years younger than their husbands. If TIAA-CREF is ordered by the courts to use merged-gender tables on funds already contributed, as the litigants demand, the result will be a 
transfer of considerable wealth from those males who have male, younger female, or no designated survivors, to those females who have female, older male, or no designated survivors. TIAA-CREF estimates the amount of this transfer to be $\$ 2.1$ billion. ${ }^{158}$ Alternatively, the institutions could contribute additional funds to "top off' the females' existing annuity accounts so that their promised periodic payments would equal those of similarly situated males. But even assuming that the institutions could or would allocate funds for this purpose and that the institutions at which the employees formerly were employed could be assessed their shares, the institutions would be vulnerable to lawsuits by their male employees, who could plausibly charge them with sex discrimination. ${ }^{137}$

Those employers, including most nonacademic firms, that do not provide their employees with immediately vested, portable retirement funds, also can avoid the effects of the prohibition of sexdistinct mortality tables by opting for a trusteed, self-insurance plan. Under such a plan, the employer would make annual contributions, usually deposited with a bank or trust company, in amounts that an actuary calculated to be sufficient to pay the promised pensions to his employee group. ${ }^{168}$ Companies employing

158 For people retiring on and after January 1, 1982, based on the following assumptions: first, the negatively affected parties do not change the annuity elections that past experience indicates they would make; and second, the rate of return on TIAA and CREF investments are $9 \%$ and $7 \%$ before retirement and $9.5 \%$ and $4 \%$ thereafter, and the discount rate is zero (that is, future expected payments are summed). The first assumption works to understate and the second to overstate the amount. Memorandum No. 3, Oct. 2, 1981, at 6, submitted by Rogers \& Wells, Counsel to TIAA-CREF, to Hon. Timothy T. Ryan, Solicitor, Department of Labor, in response to OFCCP Proposed Reg. $§ 60-1.21$ (c)(1), 46 Fed. Reg. 42,968, 42,985 (1981) (to be codified at 41 C.F.R. pt. 60) (proposed Aug. 25, 1981) (memorandum on file with University of Chicago Law Review).

${ }^{187}$ Albert Lewis, the New York Superintendent of Insurance, rejected TIAA-CREF's application for approval of a unisex table on Jan. 27, 1981. He cited

three separate sections of New York law that would be violated by its adoption. Describing the table as "unfair, unjust, inequitable and misleading," Mr. Lewis said the use of a new mortality basis would discriminate against men because it "results in a lower total income for males and a higher income benefit for females as compared to the amount of total income which would have been payable had the sex-distinct basis been retained."

....

... "[T]he company has not reserved the contractual right to make unilateral amendments as to age or sex. Without such right, the insurer cannot unilaterally modify these individual contracts as a matter of law where such change will discontinue the use of age or sex as a basis for determining benefits."

Quoted in Fenske, supra note 105, at 14.

15s Actuaries' Brief, supra note 135, at A-7; 1 J. Greider \& W. BeAdLES, supra note 27, at 357-58. 
mostly females, however, would benefit from purchasing coverage from an insurance company because the insurer would have to use a unisex table. Thus insurance companies, including TIAA-CREF, would come to be dominated by female annuitants, shifting the balance even further away from males. Referring to Table 5, if $75 \%$ of the annuitants were female and $25 \%$ were male, a male's $\$ 100,000$ retirement investment that yielded $6 \%$ would have a present value of $\$ 87,807$, a decrease of $12.2 \%$ rather than the $8.5 \%$ shown in Table 5 for a 50-50 mix.

Companies with relatively few employees probably could not use a trusteed plan because random fluctuations in their actual experience could "break the bank." Hence, they would either have to use an insurance company (if there were any that would still write annuities under a mandated unisex mortality table), not offer nonvested retirement benefits, and/or attempt to employ fewer females.

\section{Implications of Prohibiting the Use of Sex-Distinct Mortality Tables for All Insurers}

Some advocates of merged-gender tables, particularly Bernstein and Williams, recognize that if the Manhart decision is limited to employer-operated pension plans, the costs of employing women would increase, thereby disadvantaging them. ${ }^{169}$ Bernstein 'and Williams therefore would not permit employers' self-insured plans or insurance companies that provide employment-derived annuities to consider the gender composition of the work force covered. They appear to want to require all retirement plans and annuities purchased for or by employees to use the same unisex mortality table. ${ }^{180}$

Bernstein and Williams, almost alone among the commentators, correctly assess the extent to which sex-distinct mortality tables would have to be outlawed. But they do not carry their reasoning far enough. How can a trusteed, self-insurance plan be required to use a universal unisex table if, as they admit, women

169 Bernstein \& Williams, supra note 13 , at 1243 , note that

[w] hether [the employer] apportions the contributions equally among all employees or actually contributes more for his female employees makes no difference; he knows that his pension costs are higher because he employs women. Thus, he has a powerful disincentive to hiring women, which will obviously 'tend to deprive' them of employment opportunities in violation of the statute.

${ }_{180}$ Id. at 1246-47. 
tend to live longer than men, and all the employer needs to do is deposit enough funds to pay the promised pensions? In fact, as they understand, the amount required will depend on the actual male-female configuration of the potential retirees. And although insurance companies might be required legally to use only a single unisex table, assuming the McCarran-Ferguson Act $^{161}$ is repealed or amended or the states individually mandate a universal unisex mortality table, ${ }^{162}$ the effects of the legislation can be avoided by allowing employees to invest their retirement funds as they see fit, or by withdrawing the pension fringe benefit where the work force is predominantly female. Of course, the prohibition against sexdistinct mortality tables could be applied throughout the insurance industry, but then the result would also be significantly higher life insurance premiums for females. ${ }^{163}$

Finally, the effects of adverse selection on the availability of annuities and life insurance should be emphasized. It probably is the case that the advantages of insurance are sufficient to overcome initially the disadvantages to males of a mandated unisex mortality table for annuities and to females for life insurance, particularly when administrative costs are reduced by group purchase by or through an employer. But as some males forgo annuities and some females, life insurance, the disadvantages to those remaining increase. At the same time, more females will find it advantageous to buy annuities, and males to buy life insurance. This destructive effect of adverse selection has previously been experienced by insurers. ${ }^{164}$ There is no reason to believe that it will not happen again.

\section{ConcLusion}

In Manhart, Justice Stevens wrote that "we do not suggest that [Title VII] was intended to revolutionize the insurance and pension industries. All that is at issue today is a requirement [by the employer] that men and women make unequal contributions to

16115 U.S.C. $\$ \S 1011-1015$ (1976).

${ }_{162}$ The author of the Columbia Comment, supra note 10, at 1398, notes that "[i]n none of these states [with equal rights amendments to their constitutions] have premium rate differentials [based on the gender of the insured] been abolished" (footnote omitted).

${ }^{103}$ The Nondiscrimination in Insurance Bill, H.R. 100, 97th Cong., 1st Sess., 127 Cong. REc. H25 (daily ed. Jan. 5, 1981), if enacted, would do just this. Support for it appears to have diminished when the effect on life insurance premiums payable by women was realized.

set See, e.g., Bailey group, supra note 10, at 784-85. 
an employer-operated pension fund." ${ }^{18 s}$ Unfortunately, Justice Stevens misunderstood the economics of pension benefits and exhibited considerable naiveté. The value to an individual employee of a pension benefit given in the present period as compensation is measured by the present value of the expected stream of promised payments plus the utility to the person of avoiding the effects of risk. This expectation is a function of the individual's life expectancy. As discussed above, there is considerable evidence that a person's gender is a valid and useful predictor of that person's life expectancy. To forbid use of this predictor is to discriminate unfairly. The Attorney General of the state of Washington recognized this problem in an opinion; citing Griggs v. Duke Power Co., ${ }^{168}$ he stated: "equality of treatment may be denied as much by equal application of a single standard to persons unequally situated as by application of unequal standards to persons equally situated."167

If this admonition is disregarded, and the use of sex-distinct mortality tables in employment-related pensions is prohibited, workers are likely to be denied the benefits of annuities or will have to pay the higher costs of alternative arrangements. If these costs would purchase benefits for a disadvantaged group, or if they alleviated the invidious treatment of women or another group that has been discriminated against unfairly, the change might be considered worthwhile. But such would not be the case in this situation. If Manhart is extended, the result not only will be unfair discrimination against individuals because of gender, but the potential destruction of annuities and life insurance, as the inexorable effects of adverse selection work their havoc. 